\title{
Loss of Glutamate Decarboxylase mRNA-containing Neurons in the Rat Dentate Gyrus following Pilocarpine-induced Seizures
}

\author{
André Obenaus, ${ }^{1}$ Monique Esclapez, ${ }^{1}$ and Carolyn R. Houser ${ }^{1,2}$ \\ ${ }^{1}$ Brain Research Institute and Department of Anatomy and Cell Biology, University of California at Los Angeles, and \\ ${ }^{2}$ Neurology and Research Services, VA Medical Center, West Los Angeles, Wadsworth Division, Los Angeles, California \\ 90024
}

In situ hybridization methods were used to determine if glutamic acid decarboxylase (GAD) mRNA-containing neurons within the hilus of the dentate gyrus are vulnerable to seizure-induced damage in a model of chronic seizures. Sprague-Dawley rats were injected intraperitoneally with pilocarpine, and the hippocampal formation was studied histologically at $1,2,4$, and 8 week intervals after pilocarpineinduced seizures. In situ hybridization histochemistry, using a digoxigenin-labeled GAD cRNA probe, demonstrated a substantial decrease in the number of GAD mRNA-containing neurons in the hilus of the dentate gyrus in the pilocarpine-treated rats as compared to controls at all time intervals. Additional neuroanatomical studies, including cresyl violet staining, neuronal degeneration methods, and histochemical localization of glial fibrillary acidic protein, suggested that the decrease in the number of GAD mRNAcontaining neurons was related to neuronal loss rather than to a decrease in GAD mRNA levels. The loss of GAD mRNAcontaining neurons in the hilus contrasted with the relative preservation of labeled putative basket cells along the inner margin of the granule cell layer. Quantitative analyses of labeled neurons in three regions of the dentate gyrus in the 1 and 2 week groups showed statistically significant decreases in the mean number of GAD mRNA-containing neurons in the hilus of both groups of experimental animals. No significant differences were found in the molecular layer or the granule cell layer, which included labeled neurons along the lower margin of the granule cell layer. The results indicate that, in this model, a subpopulation of GAD mRNAcontaining neurons within the dentate gyrus is selectively vulnerable to seizure-induced damage. Such differential vulnerability appears to be another indication of the heterogeneity of GABA neurons.

[Key words: glutamic acid decarboxylase (GAD), GABA, in situ hybridization, temporal lobe epilepsy, status epilepticus, hippocampus, pilocarpine]

Received Jan. 26, 1993; revised Apr. 7, 1993; accepted Apr. 29, 1993.

This work was supported by VA medical research funds and by NS21908. WC gratefully acknowledge Dr. A. Tobin for providing the GAD65 cDNA; Dr. D. Guthrie for assistance with the statistical analysis; $S$. Tahtakran for processing the tissue for in situ hybridization histochemistry; S. Prasarnsuk, E. Lei, and M. Tero for assistance with other neuroanatomical methods; and D. Chang for photographic work.

Correspondence should be addressed to Dr. C. R. Houser, RRI 73-364 CHS, Brain Research Institute, UCLA, Los Angeles, CA 90024-1761.

Copyright @ 1993 Society for Neuroscience $0270-6474 / 93 / 134470-16 \$ 05.00 / 0$
The relative vulnerability of GABA neurons to excitotoxic and ischemic damage has been debated for many years. Early immunohistochemical demonstrations of a decrease in GABAergic terminals in a model of cortical focal epilepsy (Ribak et al., 1979) led to the widely accepted suggestion that GABA neurons might be particularly vulnerable to many types of insults and that their loss could be a critical factor in the development of seizure activity (Krnjević, 1983; Roberts, 1984). Electrophysiological demonstrations of a loss of inhibition following excitotoxic damage in the hippocampal formation provided support for this idea (Sloviter and Damiano, 1981; Sloviter, 1983). However, in subsequent immunohistochemical studies, a loss of neurons containing GABA or glutamic acid decarboxylase (GAD), the synthesizing enzyme for GABA, was not observed in several animal models of seizure disorders that involved damage within the hippocampal formation (Köhler, 1983; Sloviter, 1987; Franck et al., 1988; Cavalheiro, 1990; Davenport et al., 1990b; for review, see Houser, 1991). The idea that GABA neurons might in fact be relatively resistant to excitotoxic damage began to emerge.

The hilus of the dentate gyrus has become a region of major interest in studies of excitotoxic damage in the hippocampal formation because some neurons in the hilus are extremely vulnerable to damage from a variety of insults. Since neurons of the dentate hilus include several morphologically and chemically distinct types of neurons (Amaral, 1978; Amaral and Campbell, 1986; Sloviter and Nilaver, 1987), specific subgroups of hilar neurons could be damaged selectively, and thus it is important to determine the neurochemical identity of the vulnerable neurons. There is now considerable evidence that several types of peptide-containing neurons in the hilus are susceptible to excitotoxic and ischemic injury (Johansen et al., 1987; Sloviter, 1987; Freund et al., 1990; Ylinen et al., 1991; Sperk et al., 1992). However, it remains uncertain whether GABA neurons within the hilus are similarly susceptible to damage or whether they constitute a group of neurons that are relatively invulnerable to excitotoxic insults. This issue has been difficult to resolve, in part because of difficulties in consistently labeling GABA neurons in the hilus with immunohistochemical methods for localization of GAD and GABA. Some investigators have described a substantial population of GAD-containing neurons in the dentate hilus of normal animals after colchicine treatment (Ribak et al., 1978; Seress and Ribak, 1983; Kosaka et al., 1988) or following the use of special fixatives (Mugnaini and Oertel, 1985). However, others have found a relatively low number of GABA-immunoreactive neurons in this region 
(Gamrani et al., 1986; Sloviter and Nilaver, 1987). The latter findings could indicate that there are indeed only a small number of GABA neurons in this region or could reflect low levels of GABA or GAD within the cell bodies that make their identification difficult with current immunohistochemical methods.

Without a method for consistently labeling the hilar GABA neurons, an adequate evaluation of their potential loss has been impossible. Recently, in situ hybridization methods have been used to visualize neuronal cell bodies that contain GAD mRNAs in many regions of the CNS (Wuenschell et al., 1986; Chesselet et al., 1987; Julien et al., 1987; Ferraguti et al., 1990; Benson et al., 1991; Erlander et al., 1991; Esclapez et al., 1993). The findings have demonstrated that GAD mRNA-labeled neurons correspond very closely to known GABA neurons as determined by previous immunohistochemical studies, but in some instances the in situ hybridization methods allow clearer detection of the cell bodies of these neurons than immunohistochemical methods. This is particularly evident in the hippocampal formation, for, with in situ hybridization methods, numerous GAD mRNA-containing neurons can be visualized in the hilus of the dentate gyrus in normal animals (Houser and Esclapez, 1991). With these methods, it should now be possible to determine the location and relative numbers of such GAD mRNA-containing neurons in various experimental paradigms.

The pilocarpine model of chronic seizures was chosen for examining the vulnerability of hilar GABA neurons in the present study. In this model, an initial period of severe seizure activity is produced by the systemic administration of pilocarpine (Turski et al., 1983, 1989). Following the acute seizure episode, the animals show relatively normal behavior for several weeks, and then a high percentage of the animals develop spontaneous recurrent seizures (Cavalheiro et al., 1991). This model is of particular interest because the sequence of events, from a severe seizure episode to a quiescent period and then to spontaneous seizures, is similar to that observed in some humans with temporal lobe epilepsy (Leite et al., 1990).

In the pilocarpine model, as well as other models of temporal lobe epilepsy, severe seizure activity can cause damage to widespread regions of the CNS, but neurons of the hippocampal formation and related limbic structures are often most severely affected (Turski et al., 1986). The present study focused on the effects of pilocarpine-induced seizure activity on hilar neurons of the dentate gyrus not only because of their known sensitivity to damage but also because of their probable importance in regulating the levels of activity within the hippocampal formation (Scharfman and Schwartzkroin, 1990a,b; Müller and Misgeld, 1991; Heinemann et al., 1992). The major goal was to determine if the number of GAD mRNA-containing neurons in the hilus was decreased several weeks after an initial period of severe seizure activity. Nonradioactive in situ hybridization methods were used to identify GAD mRNA-containing neurons at intervals of $1,2,4$, and 8 weeks following severe seizures induced by the systemic administration of pilocarpine.

A preliminary report of this study has been published $(\mathrm{Ob}-$ enaus et al., 1992).

\section{Materials and Methods}

\section{Animals}

Sustained seizures were induced in young adult male Sprague-Dawley rats (150-200 gm; Harlan Sprague-Dawley) by the administration of pilocarpine, a muscarinic cholinergic agonist. The injection protocols were similar to those described previously (Turski et al., 1983; Caval-
Table 1. Number of control and pilocarpine-treated rats used for in situ hybridization of GAD65 mRNA at each time interval following pilocarpine administration

\begin{tabular}{lll}
$\begin{array}{l}\text { Time after } \\
\text { injection }\end{array}$ & Control rats & $\begin{array}{l}\text { Pilocarpine- } \\
\text { treated rats }\end{array}$ \\
\hline 1 week & 2 & 6 \\
2 weeks & 2 & 6 \\
1 month & 2 & 4 \\
2 months & 2 & 2 \\
\hline
\end{tabular}

heiro et al., 1987). A low dose of the cholinergic antagonist methyl scopolamine nitrate $(1 \mathrm{mg} / \mathrm{kg}$, i.p.; Sigma, St. Louis, MO) was administered $30 \mathrm{~min}$ prior to pilocarpine injection to minimize peripheral cholinergic effects (Baez et al., 1976; Turski et al., 1983). Animals then received a single injection of pilocarpine hydrochloride $(325-350 \mathrm{mg}$ / $\mathrm{kg}$, i.p.; Sigma). Animals were placed in an observation box and monitored for a minimum of $5 \mathrm{hr}$ to assess the severity and length of behavioral seizures, which have been described previously (Turski et al., 1983; Cavalheiro et al., 1991). After 4-8 hr of behavioral seizures, the animals gradually resumed normal motor activity but showed little eating or drinking behavior. To minimize mortality and weight loss, animals were injected with lactated Ringer's solution $(2 \mathrm{cc} / \mathrm{d}$, s.c.) and fed moist rat chow until they began to gain weight, typically within 3$7 \mathrm{~d}$.

Thirty-nine rats were injected with pilocarpine, and $62 \%(n=24)$ of the animals survived the acute seizure period. Only animals that had robust behavioral seizures in excess of $3-4 \mathrm{hr}$ were included in the study $(n=18)$; six rats were excluded because they did not show prolonged behavioral seizures. The animals were studied with neuroanatomical methods at 1,2,4, and 8 weeks after pilocarpine-induced seizures. Table 1 summarizes the number of control and experimental rats used at each of the four intervals.

I hroughout their survival periods of $1-8$ weeks, the animals were observed periodically in the vivarium for general behavior and spontaneous seizures. Approximately once a week the rats were videotaped for $12 \mathrm{hr}$ overnight, and the tapes were later viewed for the occurrence of spontaneous seizures. One of six animals in the 2 week experimental group and all animals in the 4 and 8 week experimental groups were observed to have at least one spontaneous seizure.

In addition to the animals that were studied at 1-8 weeks after pilocarpine injection, other pilocarpine-treated animals were studied at shorter postinjection intervals to evaluate the time course of neuronal degeneration within the hippocampal formation. Two or three animals were studied at each time interval of $12,18,24,48$, and $72 \mathrm{hr}$ after pilocarpine administration.

\section{Tissue preparation}

Rats were deeply anesthetized with sodium pentobarbital $(60 \mathrm{mg} / \mathrm{kg})$ and perfused intracardially with a fixative solution of $4 \%$ paraformaldehyde in $0.12 \mathrm{~m}$ Millonig's phosphate buffer ( $\mathrm{pH}$ 7.3). Rats received approximately $300 \mathrm{ml}$ of this fixative per $100 \mathrm{gm}$ of body weight. Following perfusion, the brains were left in situ for $1 \mathrm{hr}$ at $4^{\circ} \mathrm{C}$, and then removed from the cranial cavity and postfixed for $1 \mathrm{hr}$ in the same fixative. After thorough rinsing in buffer $(3 \times 30 \mathrm{~min})$, blocks of forebrain containing the hippocampal formation were cryoprotected in a $20 \%$ sucrose solution overnight at $4^{\circ} \mathrm{C}$. Blocks were then frozen and sectioned coronally at $30 \mu \mathrm{m}$ on a cryostat. Serial sections were individually placed into $1 \mathrm{ml}$ microcentrifuge tubes containing a cryoprotectant solution (Watson et al., 1986; Lu and Haber, 1992) and stored at $-20^{\circ} \mathrm{C}$ until histological processing.

Every 10th section was stained with cresyl violet to determine the general histological characteristics of the tissue and the location of the sections within the rostral-caudal extent of the hippocampal formation. Four to six sections from each animal were processed with in situ hybridization methods for localization of GAD mRNA. These sections were selected at regular intervals of $300 \mu \mathrm{m}$, beginning at the rostral part of the hippocampal formation in which there was a complete, typical profile of the dentate gyrus. The series thus included sections from the rostral to middle levels of the dentate gyrus. Other series of sections at similar levels were processed with neuronal degeneration 
methods and immunohistochemical methods for localization of glial fibrillary acidic protein (GFAP).

\section{In situ hybridization histochemistry}

Probe synthesis. The antisense and sense GAD riboprobes used in this study were produced by in vitro transcription of a previously described GAD CDNA that encodes a GAD isoform with a molecular size of 65 $\mathrm{kDa}$ (GAD65) (see Erlander and Tobin, 1991, for review; the GAD cDNA was kindly provided by A. Tobin, UCLA). GAD65 mRNA was selected for localization in the present study because previous in situ hybridization studies have demonstrated that GAD65 mRNA is present in all known groups of GAD- and GABA-containing ncurons in the hippocampal formation of normal rats (Houser and Esclapez, 1991), and biochemical studies have described relatively high levels of GAD65 in the hippocampal formation (Martin et al., 1991a). GAD65 cDNA (2.4 kilobases), containing the complete coding sequence for rat GAD65 was isolated from a $\lambda$ zap II rat hippocampal library (Erlander et al., 1991) and subcloned into the Bluescript transcription vector (SK Polylinker, Stratagene Cloning Systems, La Jolla, CA) in both orientations in order to obtain antisense and sense riboprobes. The recombinant plasmids containing the GAD65 cDNA insert were linearized with Xba I and transcribed with T7 RNA polymerase in the presence of digoxigenin-11-UTP, using a nonradioactive RNA labeling kit (Boehringer Mannheim, Indianapolis, IN). This labeling and the nonradioactive in situ hybridization methods used for detection of GAD65 mRNA (see following section) have been described in detail previously (Esclapcz ct al., 1993).

In situ hybridization methods. Prior to hybridization, free-floating sections were pretreated with the following solutions: $0.02 \mathrm{~N} \mathrm{HCl}$ for $10 \mathrm{~min} ; 0.01 \%$ Triton $\mathrm{X}-100$ in $1 \times$ phosphate-buffered saline (PBS) for $3 \mathrm{~min} ; 0.25 \mu \mathrm{g} / \mathrm{ml}$ proteinase $\mathrm{K}$ in $50 \mathrm{~mm}$ Tris buffer, $5 \mathrm{~mm}$ EDTA, pH 7.4 for $10 \mathrm{~min}$; two rinses $(10 \mathrm{~min}$ each) in $1 \times$ PBS with $0.2 \%$ glycine. The sections were incubated in a prehybridization solution containing $50 \%$ formamide, $750 \mathrm{~mm} \mathrm{NaCl}, 25 \mathrm{~mm}$ EDTA, $25 \mathrm{~mm}$ piperazine- $N, N^{\prime}$-bis(2-ethanesulfonic acid) (PIPES), $0.2 \%$ sodium dodecyl sulfate, $0.02 \%$ Ficoll, $0.02 \%$ polyvinylpyrrolidone, $0.02 \%$ bovine serum albumin, $250 \mu \mathrm{g} / \mathrm{ml}$ polyA, and $250 \mu \mathrm{g} / \mathrm{ml}$ salmon sperm DNA for $1 \mathrm{hr}$ at room temperature. Sections were then incubated in the hybridization solution that consisted of the prehybridization solution with the addition of $0.2 \mathrm{ng} / \mu$ l digoxigenin-labeled RNA probe, $100 \mathrm{~mm}$ dithiothreitol, and $4 \%$ dextran sulfate for a minimum of $16 \mathrm{hr}$ at $50^{\circ} \mathrm{C}$ Following hybridization, sections were treated with ribonuclease A ( 50 $\mu \mathrm{g} / \mathrm{ml}$ in $0.5 \mathrm{M} \mathrm{NaCl}, 10 \mathrm{~mm}$ sodium thiosulfate, $1 \mathrm{~mm}$ EDTA, $10 \mathrm{~mm}$ Tris- $\mathrm{HCl}$ buffer, $\mathrm{pH} 8.0$ ) for $30 \mathrm{~min}$ at $37^{\circ} \mathrm{C}$. This was followed by lowto high-stringency washes in $2 \times$ saline sodium citrate (SSC) with 10 mM sodium thiosulfate for $2 \mathrm{hr}$ at room temperature and $0.1 \times \mathrm{SSC}, 10$ mM sodium thiosulfate for $30 \mathrm{~min}$ at $55^{\circ} \mathrm{C}$.

Sections were then processed for immunodetection of the digoxigenin label with the basic reagents of a nonradioactive nucleic acid detection kit (Boehringer Mannheim). The sections were rinsed twice in $100 \mathrm{~mm}$ Tris- $\mathrm{HCl}$ buffer, $150 \mathrm{~mm} \mathrm{NaCl}$, pH 7.5 (buffer 1); incubated in $0.5 \%$ blocking reagent and $0.3 \%$ Triton X-100 in the same buffer for $1 \mathrm{hr}$; and incubated overnight at $4^{\circ} \mathrm{C}$ in alkaline phosphatase-conjugated antibodies to digoxigenin diluted $1: 1000$ in buffer 1 containing $0.3 \%$ Triton. On the following day, the sections were washed for $1.5 \mathrm{hr}$ in buffer 1 and $20 \mathrm{~min}$ in $100 \mathrm{mM}$ Tris- $\mathrm{HCl}$ buffer, $\mathrm{pH} 9.5$, containing $100 \mathrm{~mm}$ $\mathrm{NaCl}$ and $50 \mathrm{mM} \mathrm{MgCl}$ (buffer 2). The sections were then incubated in a chromogen solution containing $45 \mu \mathrm{l}$ of the nitroblue tetrazolium solution, $35 \mu \mathrm{l}$ of the 5-bromo-4-chloro-3-indolyl phosphate reagent, and $2.4 \mathrm{mg}$ of levamisole (endogenous alkaline phosphatase inhibitor) in $10 \mathrm{ml}$ of buffer 2 . Preliminary studies indicated that optimal staining, defined as strong specific neuronal labeling with a low background of general tissue staining and no nonspecific staining of neurons, was obtained by $5 \mathrm{hr}$ in the chromogen solution, and this color reaction time was used for all sections processed in the study. The reaction was stopped by rinsing the sections in $10 \mathrm{~mm}$ Tris- $\mathrm{HCl}(\mathrm{pH} \mathrm{8.0)}$ with $1 \mathrm{~mm}$ EDTA. The sections were mounted on gelatin-coated slides, dried, and coverslipped using an aqueous mounting medium (Crystal/Mount, Biomeda, Foster City, CA).

\section{Neuronal degeneration methods}

Silver impregnation methods were used to identify degenerating neurons in tissue from animals at both short (12-72 hr) and long (1-8 weeks) intervals after pilocarpine injection. The neuronal degeneration meth- ods were a modification of the methods of Gallyas et al. (1980) and have been described in detail by Nadler and Evenson (1983).

\section{Immunohistochemistry for GFAP}

Immunohistochemical methods for localization of GFAP were used to determine the location and extent of astrocytic changes. The sections were incubated in primary antiserum to GFAP (diluted 1:5000-7000; DAKO, Carpinteria, CA) overnight at $4^{\circ} \mathrm{C}$, and were then processed with standard avidin-biotin immunohistochemical methods (ABC Elite, Vector, Burlingame, CA).

\section{Data analysis}

Sections from control and experimental animals were examined by light microscopy to determine the distribution of GAD mRNA-containing neurons, and the patterns of neuronal degeneration, cell loss, and reactive gliosis. Following the qualitative analysis, quantitative studies of GAD mRNA-containing neurons in the dentate gyrus were conducted to determine the extent of labeled cell loss in the hilus and to compare the relative numbers of labeled neurons in control and experimental specimens in specific regions of the dentate gyrus. Quantitative data were obtained from the dentate gyrus bilaterally in four sections from each control and pilocarpine-treated animal in the 1 and 2 week groups. The numbers of GAD mRNA-containing neurons per area were assessed in three regions (molecular layer, granule cell layer, and hilar region) of the dorsal (rostral to middle) dentate gyrus.

The dentate gyrus of sections processed for in situ hybridization of GAD mRNA-containing neurons was photographed and printed at a magnification of $100 \times$. A composite photograph of each dentate gyrus was covered with a clear acetate sheet on which areas and labeled neurons were delineated. Three regions of the dentate gyrus were outlined (Fig. 1): (1) the molecular layer, which extended from the outer edge of the granule cell layer to the hippocampal fissure dorsally and the ventricular border ventrally; (2) the granule cell layer, which included the compact layer of granule cells and all neurons in the lower margin of the granule cell layer, some of which extended in to the immediately adjacent subgranular region; and (3) the hilar region that was operationally defined as a $100-\mu \mathrm{m}$-wide region deep to the granule cell layer. Lines drawn parallel to the granule cell layer, at a distance of $100 \mu \mathrm{m}$ deep to the inner border of the dorsal and ventral blades of the dentate gyrus, intersected near the apex of the hilus and enclosed the hilar region (Fig. $1 B$ ). This operational definition of the hilar region excluded the CA3 field between the dorsal and ventral blades of the dentate gyrus. The lateral border of the dentate gyrus was delineated by a straight line that connected the outer borders of the dorsal and ventral blades of the granule cell layer.

After the three regions had been outlined for each section, GAD mRNA-containing neurons in the photomicrographs were verified by examining each section under the microscope, and the corresponding neurons were plotted on the acetate sheet overlying the photomicrographs. Labeled neurons in each region were counted by two independent observers. Neurons that were bisected by a line demarcating a region were eliminated from the counts. However, neurons that were transected by a line but were located primarily within one region were included in the neuronal counts of that region. Area measurements of each region (molecular layer, granule cell layer, and hilar region) were made with an image analysis system (Analytical Imaging Concepts). Large blood vessels within the defined regions were excluded from the area measurements. From this data, the mean number of GAD mRNAcontaining neurons per $10,000 \mu \mathrm{m}^{2}$ in each region was determined.

The data were analyzed statistically by a mixed model analysis of variance (ANOVA) to determine if there were significant differences in the number of neurons per area between groups (control and pilocarpinetreated rats), in each region (molecular layer, granule cell layer, and hilar region), and at each time interval ( 1 and 2 weeks). When significant differences were found, post hoc statistical comparisons of means were made between groups with a Student's $t$ test.

\section{Results}

Cresyl violet staining

Cresyl violet-stained sections were studied to determine the extent and location of general neuronal loss within the hippocampal formation following pilocarpine-induced seizures. At all time intervals, the most consistent and extensive cell loss was 

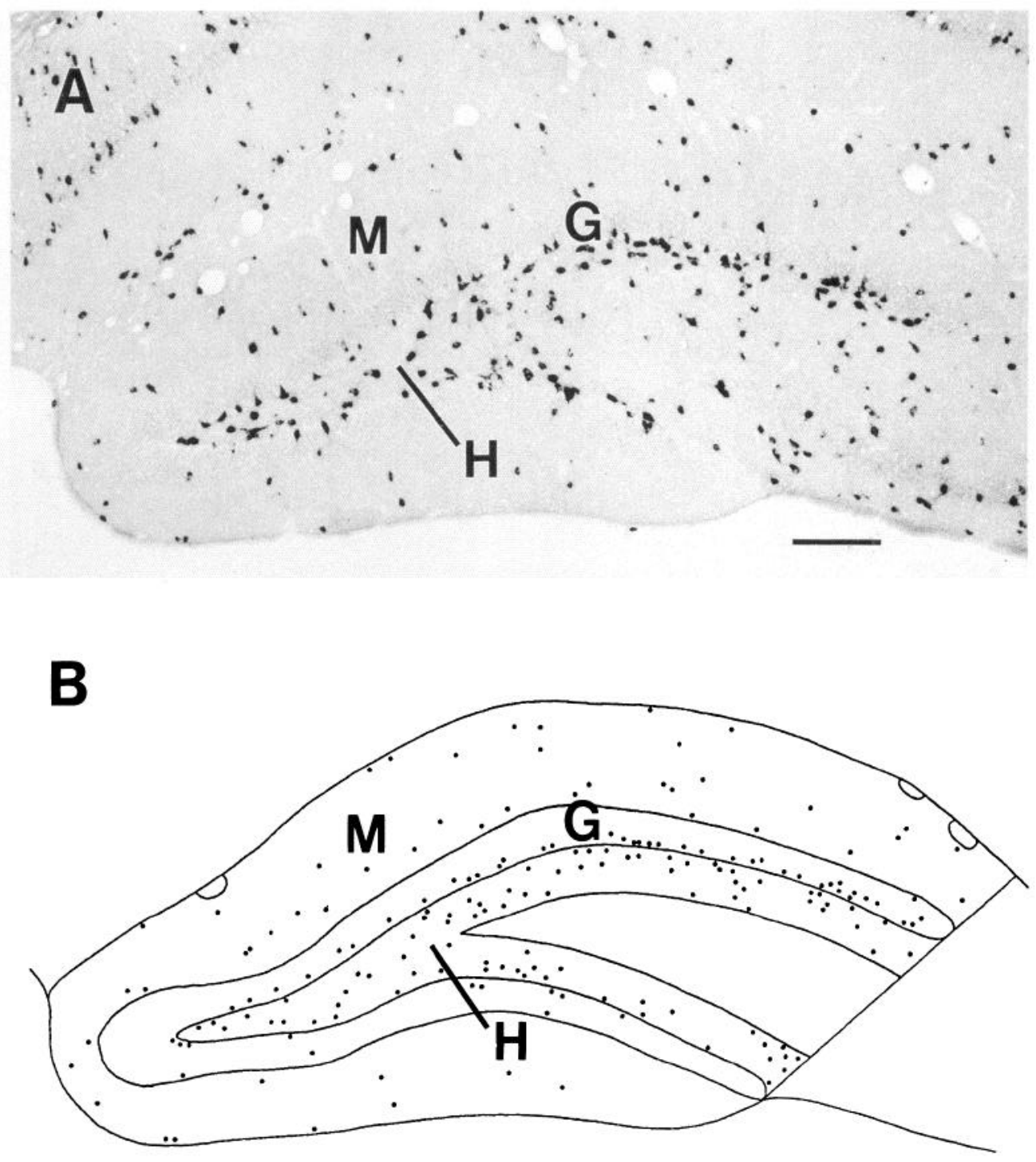

Figure 1. GAD mRNA-containing neurons in the normal dentate gyrus. $A$, Numerous labeled neurons are evident in the hilus $(H)$ as well as along the lower margin of the granule cell layer $(G)$. Labeled neurons are also dispersed within the molecular layer $(M) . B, \mathrm{~A}$ schematic drawing of part of the above section in which labeled neurons were plotted in three regions of the dentate gyrus for quantitative analysis. From such plots, the numbers of labeled neurons per area of the hilus $(H)$, granule cell layer $(G)$, and molecular layer $(M)$ were calculated. Labeled neurons in adjacent regions of the hippocampus were not included in the schematic or analysis. Scale bar, $200 \mu \mathrm{m}$ (for $A$ and $B$ ).

found in the hilus of the dentate gyrus. In sections from pilocarpine-treated rats, the number of neurons in the hilus was substantially reduced (Fig. $2 B, D$ ), as compared to that in control specimens (Fig. $2 A, C$ ), and, in most animals, a decrease in the number of cresyl violet-stained neurons was evident in all parts of the hilus. Although the loss of neurons was often quite marked, it was not complete and varying numbers of neuronal cell bodies remained within the hilar region. Pilocarpine-treated animals showed variable amounts of neuronal loss in CA3 (Fig. 2B), but this loss was seldom extensive and was often difficult to discern in cresyl violet-stained sections. Likewise, neuronal loss in the CA1 field was seldom detected in these specimens, and no loss of granule cells was evident in the cresyl violet-stained sections. Some pilocarpine-treated rats at long postinjection intervals (4 and 8 weeks) had subtle changes in the shape of the hippocampal formation, but the basic pattern of cell loss remained the same.

\section{Silver impregnation methods for neuronal degeneration}

Whereas cresyl violet staining revealed regions of neuronal loss, silver impregnation methods identified neurons that were in the process of degenerating. As early as $12 \mathrm{hr}$ after pilocarpine administration, the shortest interval at which tissue was examined in the present study, silver-impregnated (degenerating) neurons could be seen throughout the entire extent of the hilus (Fig. $3 A$ ). At $18 \mathrm{hr}$ after injection, neuronal degeneration appeared to be more advanced, as indicated by darker and more extensive labeling of the cell bodies and their dendritic processes (Fig. $3 B$, arrows). At 24, 48, and $72 \mathrm{hr}$ after pilocarpine injection, numerous degenerating neurons, as well as silver-impregnated profiles that appeared to be neuronal debris, were observed in the hilus. At these latter time intervals, minimal to moderate numbers of degenerating pyramidal neurons were present in CA3 and were also occasionally observed in CA1. Degenerating granule cells were frequently observed, but the numbers were relatively small in comparison to the total population of these neurons. At 1 week following injection, the number of degenerating neurons in the hilus was substantially less than that observed at earlier time points, suggesting that much of the hilar neuron degeneration was complete by 1 week. Very few degenerating neuronal cell bodies were observed in any region of the hippocampal formation at 2, 4, and 8 weeks after injection. However, some putative degenerating terminals and fibers were evident in neuropil regions such as the inner one-fourth of the molecular layer of the dentate gyrus and in the white matter. 

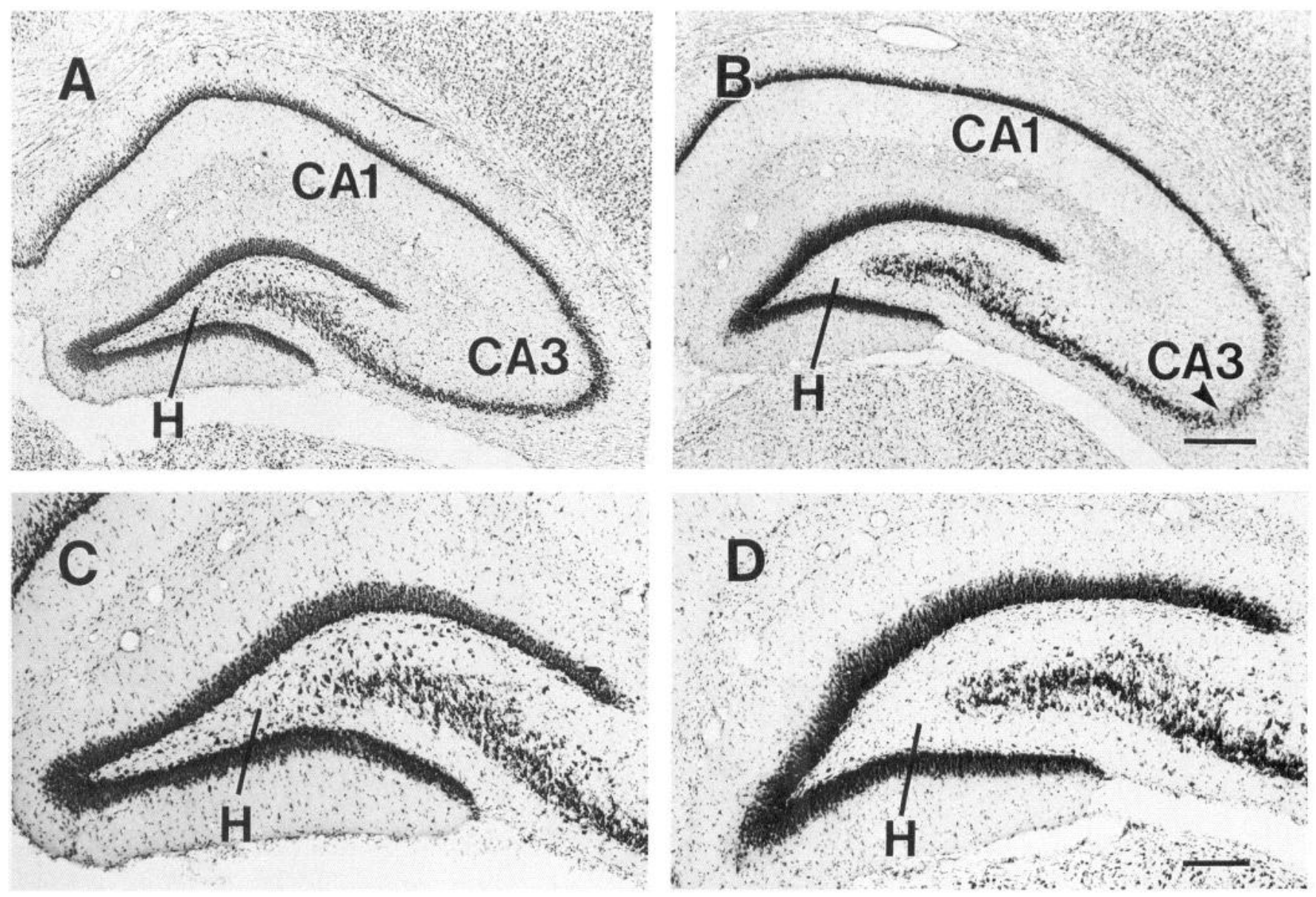

Figure 2. Cresyl violet-stained sections of the hippocampal formation of control $(A, C)$ and pilocarpine-treated $(B, D)$ rats. $A$ and $C$, In control specimens, numerous neurons are present in the hilus $(H)$ of the dentate gyrus. Neuronal cell bodies are highly concentrated and form a continuous band in the pyramidal cell layer of the CA3 and CA1 fields. $B$ and $D$, At 1 week after pilocarpine-induced seizures, there is a marked reduction in the number of neurons in the hilus $(H)$ of the dentate gyrus (compare $B$ and $D$ with $A$ and $C$ ). Slight neuronal loss is also present in some regions of CA3 ( $B$, arrowhead), but little or no cell loss is evident in CA1. Scale bars: $A$ and $B, 400 \mu \mathrm{m} ; C$ and $D, 200 \mu \mathrm{m}$.

\section{In situ hybridization for GAD mRNA-containing neurons}

Qualitative analyses. In control rats, GAD mRNA-containing neurons were found in all regions of the dentate gyrus but were most concentrated within the hilus (Figs. $1 A, 4 A$ ). These GAD mRNA-containing neurons were present throughout the entire extent of the hilus, including the apex and regions deep to the blades of the dentate gyrus (Fig. 4A). The labeled neurons had a variety of sizes and shapes. Labeling of the most proximal dendrites suggested that many of the hilar neurons were multipolar with a generally round or oval shape, but some labeled neuronal cell bodies were fusiform in shape and were oriented with their proximal dendrites parallel to the inner border of the granule cell layer. In addition to the labeled neurons in the hilus, there were numerous GAD mRNA-containing neurons within the lower margin of the granule cell layer (Fig. 4A). Many of these neurons had pyramidal-like shapes and were presumed to be dentate basket cells (Lorente de Nó, 1934; Amaral, 1978; Ribak and Seress, 1983). A few labeled neurons were located in other parts of the granule cell layer (Fig. $4 A$ ), and scattered neurons were present throughout the molecular layer of the dentate gyrus, although these neurons were sparse in comparison to those in the hilar region (Figs. 1A, 4A).

In animals at 1 and 2 weeks after pilocarpine-induced seizures, the number of GAD mRNA-containing neurons in the hilus was substantially reduced in comparison to controls (Fig. $4 B$ ). A decreased number of GAD mRNA-containing neurons was evident throughout the hilus and was observed within the apex as well as in the region deep to the blades of the dentate gyrus (Fig. 4B). The severity of labeled cell loss often appeared greatest in the central part of the hilus, that is, between the two blades of the granule cells and medial to the tip of the CA3 pyramidal cell layer (Fig. 4B). A loss of labeled neurons was readily observed in virtually all sections from each experimental animal. However, in all animals, some GAD mRNA-containing neurons remained within the hilus. These remaining labeled neurons varied in size, shape, and location within the hilus (Figs. $4 B, 5$ ), but often included some neurons in the lateral part of the hilus, beneath the lateral segment of the upper blade of granule cells (Fig. 5).

Figure 3. Neuronal degeneration in the dentate gyrus of pilocarpine-treated rats. $A$, At $12 \mathrm{hr}$ after pilocarpine treatment, numerous silverimpregnated, degenerating neurons (arrows) are found throughout the hilus $(H)$ of the dentate gyrus. Degenerating neurons are evident within the hilar region beneath the blades of the granule cell layer $(G)$ and as well as within the central hilus that lies medial to the tip of the CA3 field. In 


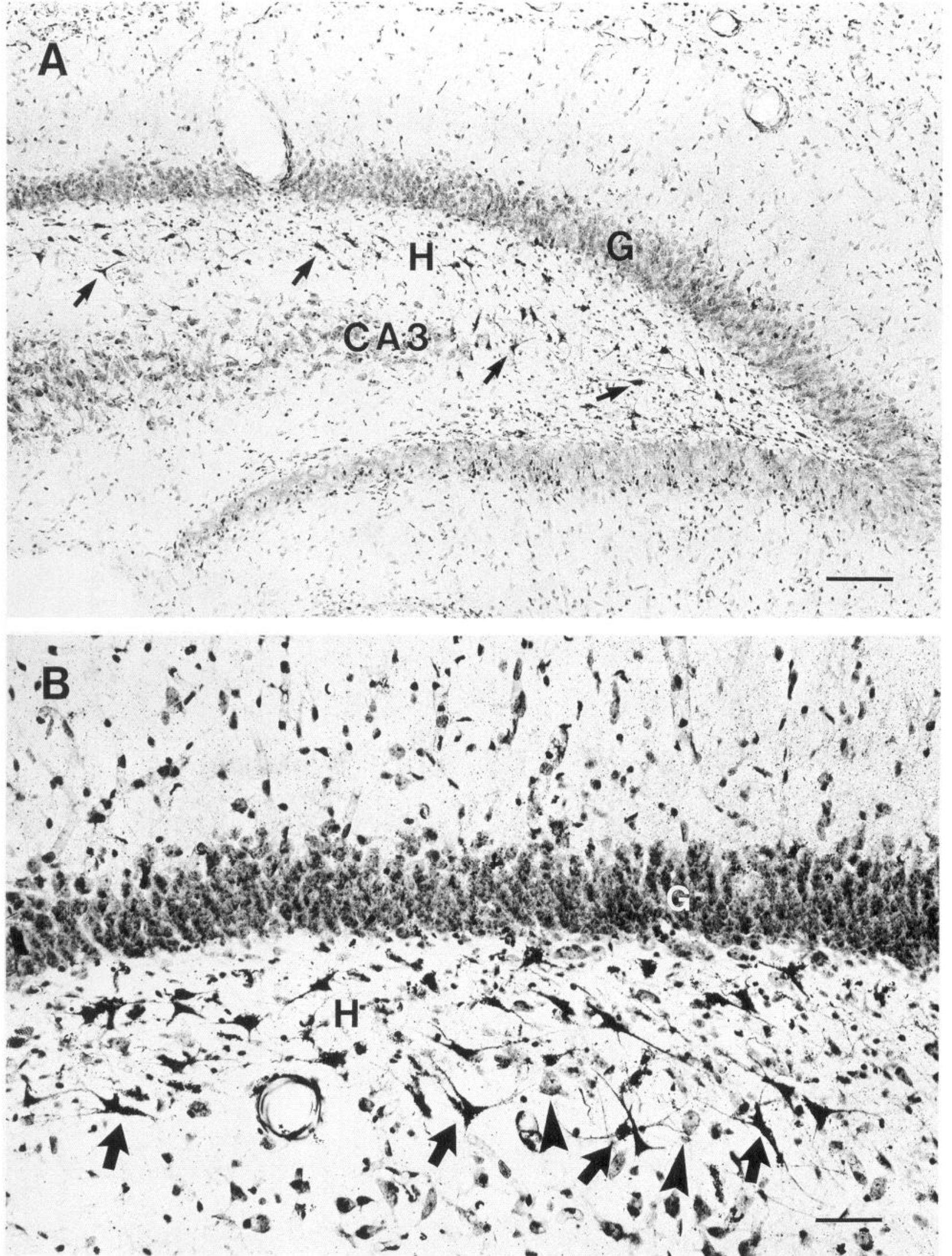

this specimen, most neurons in CA3 appear undamaged. $B$, At $18 \mathrm{hr}$ following pilocarpine administration, the hilus $(H)$ contains many silverimpregnated, darkly labeled neurons (arrows). Labeling of the cell bodies and proximal dendrites reveals the varied forms of these degenerating neurons. Some lightly labeled neurons (arrowheads) that do not appear to be degenerating are also present in the hilus. Most neurons in the granule cell layer $(G)$ did not appear to be degenerating. Scale bars: $A, 100 \mu \mathrm{m} ; B, 25 \mu \mathrm{m}$. 


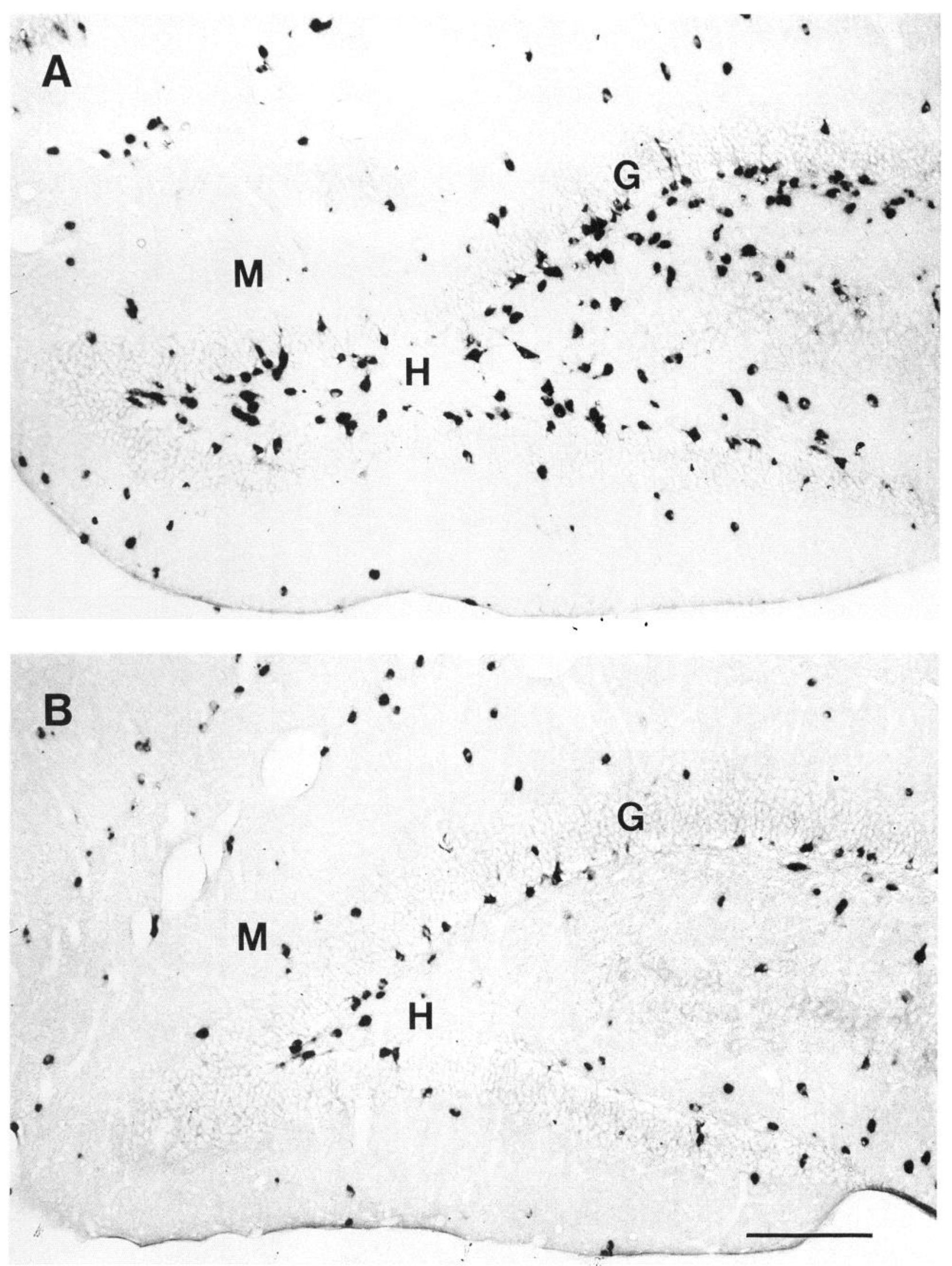

Figure 4. GAD mRNA-containing neurons in the dentate gyrus of a control $(A)$ and a pilocarpine-treated $(B)$ rat. $A$, In the normal dentate gyrus, numerous GAD mRNA-labeled neurons are present in the hilus $(H)$ where they are located in the area beneath the granule cell layer $(G)$ as well as in the central part and tip of the hilus. Many GAD mRNA-containing neurons are also present within the lower margin of the granule cell layer, and smaller numbers of labeled neurons are found in other parts of the granule cell layer $(G)$ and the molecular layer $(M)$. $B$, In an experimental specimen at 1 week after pilocarpine treatment, the number of labeled neurons throughout the hilus $(H)$ is substantially reduced. Some GAD mRNA-containing neurons are present along the lower margin of the granule cell layer $(G)$ and in the molecular layer $(M)$. Scale bar, $200 \mu \mathrm{m}$. 


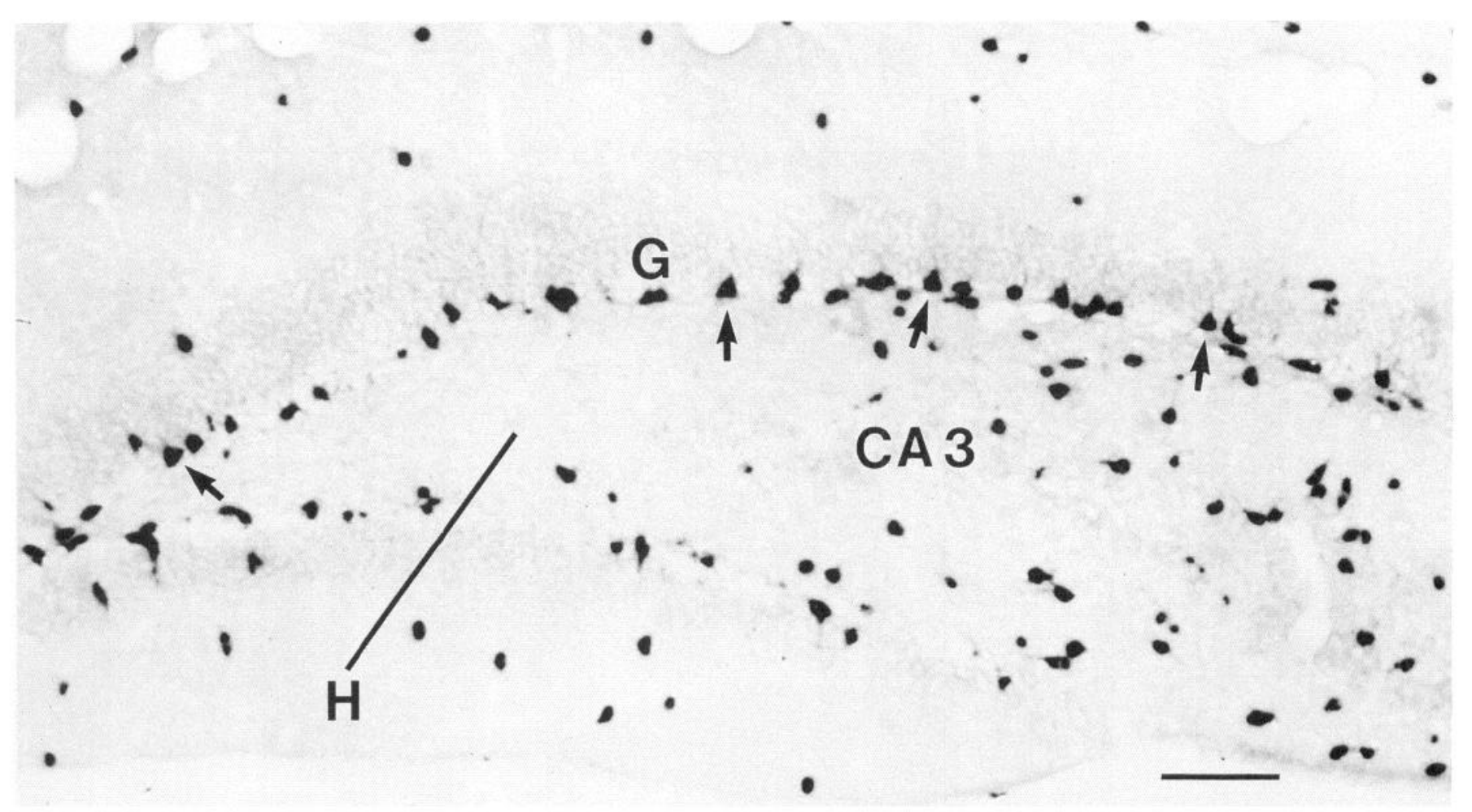

Figure 5. GAD mRNA-labeled neurons in the dentate gyrus of a pilocarpine-treated rat. At 1 week after pilocarpine-induced seizures, numerous GAD mRNA-containing neurons (arrows) remain within the lower margin of the granule cell layer $(G)$, where they virtually outline the neurondeficient hilus $(H)$. Many of these remaining neurons resemble basket cells in their shapes and location. In addition, some labeled neurons are present in the lateral part of the hilus, between the granule cell layer and inner segment of CA3. Scale bar, $100 \mu \mathrm{m}$.

In contrast to the marked decrease in the number of labeled neurons within the hilus, numerous GAD mRNA-containing neurons were present in the deepest part of the granule cell layer immediately adjacent to the hilus (Figs. $4 B, 5$ ). Many of these GAD mRNA-containing neurons were moderate to large in size, had a pyramidal-like shape (Fig. 5, arrows), and thus resembled pyramidal basket cells (Ribak and Seress, 1983). The relative preservation of these putative basket cells led to a virtual outlining of the border between the granule cell layer and hilus (Fig. 5).

In animals at 4 and 8 weeks after pilocarpine administration, mild to moderate changes in the shape of the dentate gyrus were frequently observed. In some animals, the apex of the dentate gyrus was compressed or collapsed, and the lateral regions of the dentate gyrus were often wider than normal. Despite these alterations, a reduction in the number of GAD mRNA-containing neurons in the hilus was evident.

Quantitative analyses at 1 and 2 week intervals. While loss of GAD mRNA-containing neurons in the hilus was obvious following qualitative examination (Fig. $4 B$ ), loss of labeled neurons, if present, was less evident in the granule cell and molecular layers. This prompted us to determine the relative numbers of GAD mRNA-containing neurons in three regions of the dentate gyrus, that is, the hilus, granule cell layer, and molecular layer (Fig. 1). The numbers of labeled neurons were analyzed at 1 and 2 week intervals only in order to avoid confounding variables related to the altered shape of the dentate gyrus in some pilocarpine-treated animals at 4 and 8 weeks after seizure induction.
Quantitative analyses showed no significant differences between the two control groups ( 1 and 2 weeks) in the mean number of GAD mRNA-containing neurons per area within each region of the dentate gyrus (Table 2). In contrast, there were significant differences in the mean numbers of labeled neurons between control and experimental groups at each time interval. In the hilus of the dentate gyrus, marked decreases ( $44 \%$ and $39 \%$ ) in the mean numbers of GAD mRNA-containing neurons were observed for the experimental animals at 1 and 2 week intervals, respectively, when compared to agematched controls (Fig. 6A, Table 2). These differences between experimental and control groups were statistically significant $(p$ $<0.001$, Student's $t$ test) for both groups. The mean numbers of GAD mRNA-containing hilar neurons in the 1 and 2 week experimental groups were not significantly different from each other. In the granule cell layer, which included the labeled neurons along the lower margin of the granule cell layer, and the molecular layer of the dentate gyrus, no significant differences were found in the mean numbers of GAD mRNA-containing neurons in control and pilocarpine-treated animals at 1 or 2 weeks (Fig. 6B,C; Table 2). Therefore, both qualitative and quantitative analyses indicated that the hilus was the only region of the dentate gyrus in which there was a large and consistent reduction in the number of GAD mRNA-containing neurons.

\section{Relationships among neuroanatomical changes}

Findings from the multiple methods were related to each other in the same control and experimental animals (Fig. 7). The decreased number of cresyl violet-stained neurons in the hilus 


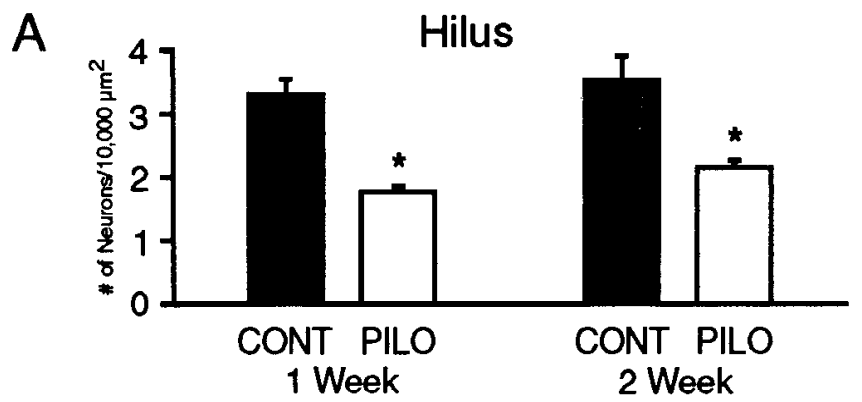

B
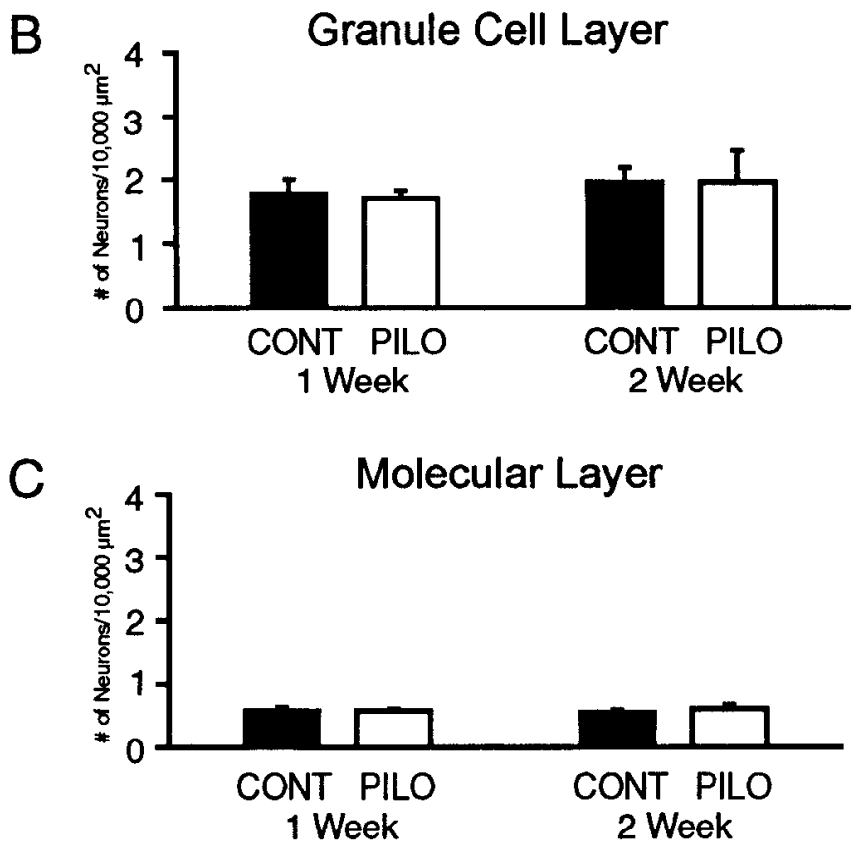

Figure 6. Histograms comparing the mean number of GAD mRNAlabeled neurons per area in control and pilocarpine-treated animals at 1 and 2 week intervals following pilocarpine-induced seizures in three regions of the dentate gyrus. Statistically significant differences $\left({ }^{*}\right)$ in the mean number of labeled neurons were found only in the hilus for both the 1 week and 2 week groups $(p<0.001$, Student's $t$ test). Error bars indicate SEM.

of experimental animals at 1-2 weeks after pilocarpine treatment (Fig. $7 A, B$ ) was consistent with a marked reduction in GAD mRNA-containing neurons in the same region (Fig. $7 C, D$ ). Staining for neuronal degeneration in adjacent sections revealed some darkly labeled, degenerating, neurons within the hilus of the pilocarpine-treated animals (Fig. $7 E, F$ ). The number of degenerating cell bodies was often relatively small, but many darkly labeled elements, suggestive of degenerating axon terminals and fibers, were evident in the hilus and inner molecular layer at these times (Fig. $7 F$, arrowheads). Immunohistochemical localization of GFAP revealed a marked increase in labeling in experimental animals as compared to controls (Fig. $7 G, H$ ), and the increased GFAP immunoreactivity in the hilus corresponded closely to the regions of neuronal loss (Fig. 7, compare $H$ with $B, D, F)$.

\section{Discussion}

Loss of GAD mRNA-containing neurons

The present findings demonstrate a marked loss of GAD mRNAcontaining neurons in the hilus of the dentate gyrus following a period of severe seizure activity induced by pilocarpine. Pre- vious studies have alluded to a loss of neurons within the hilus of pilocarpine-treated rats, but the chemical identity of these neurons was not determined (Turski et al., 1986). Biochemical descriptions of a decrease in GAD activity (approximately 20\%) in the hippocampal formation at 5-7 d after the initial seizures are consistent with the present findings (Turski et al., 1986). However, a previous immunohistochemical study of GAD-immunoreactive neurons within the hippocampal formation of chronic pilocarpine-treated animals found no change in the number of GAD-containing neurons (Cavalheiro, 1990). In the immunohistochemical study, all regions of the hippocampal formation were apparently evaluated together, and it is possible that a decrease in the number of neurons in the hilus might not have been detected. Alternatively, the size of the normal population of GAD-containing neurons in the hilus might have been underestimated with immunohistochemical methods, and thus a decrease in the number of these neurons in experimental animals might not have been evident.

The present demonstration of a loss of hilar GAD mRNAcontaining neurons in the experimental animals was dependent on first being able to label the normal complement of these neurons in control animals. The nonradioactive in situ hybridization methods used in this study allowed clear and consistent localization of numerous GAD mRNA-containing neurons in the hilus of control animals. All other groups of known GABA neurons in the hippocampal formation were also labeled with these methods, and non-GABA neurons of the hippocampal formation, such as the granule and pyramidal cells, were not labeled. The GAD mRNA-containing neurons are presumed to synthesize GAD and, in turn, GABA, and the similarities between the labeling patterns for GAD65 mRNA and the immunohistochemical localization of GAD and GABA in many brain regions support this suggestion (Erlander et al., 1991; Mercugliano et al., 1992; Esclapez et al., 1993). The possibility that the hilar neurons contain GAD65 mRNA but do not synthesize and release GABA cannot be ruled out completely. However, this seems unlikely because GAD65 is abundant in the hippocampal formation (Houser and Esclapez, 1991; Martin el al., 1991a), and biochemical studies have demonstrated that GAD65 synthesizes GABA when the enzyme is coupled to the cofactor pyridoxal $5^{\prime}$-phosphate (Erlander et al., 1991). Since GAD65 constitutes much of the apoenzyme form of GAD (GAD without bound cofactor) in the hippocampus (Martin et al., 1991b), some GAD65 may serve as a reserve that can be activated in response to local demands and may be important for the synthesis of GABA at synaptic sites (Erlander et al., 1991; Kaufman et al., 1991; Martin and Rimvall, 1993).

Despite many similarities in the localization of GAD65 mRNA and that of GAD and GABA in neuronal cell bodies in the hippocampal formation, some differences are apparent. The prominence of GAD mRNA-containing neurons in the hilus of control animals contrasts with the relatively small number of GABA-immunoreactive neurons that have been observed in the hilus in some previous immunohistochemical studies. One explanation for this difference could be that GAD, after being synthesized in the cell bodies, is rapidly transported to the axon terminals. The finding that GAD65 is particularly abundant in axon terminals (Erlander et al., 1991; Houser and Esclapez, 1991; Kaufman et al., 1991) is consistent with this possibility. The major synthesis of GABA by this GAD isoform would thus be expected to occur in the axon terminals of these neurons. The resultant low amounts of both the synthesizing enzyme and 
Table 2. Comparisons of mean number of GAD mRNA-containing neurons per area in the dentate gyrus of control and pilocarpine-treated rats

\begin{tabular}{|c|c|c|c|c|c|}
\hline Region & $\begin{array}{l}\text { Control } \\
(n=16)\end{array}$ & $\begin{array}{l}\text { Pilocarpine } \\
(n=48)\end{array}$ & $\begin{array}{l}\text { \% difference, } \\
\text { expt vs. cont }\end{array}$ & $\begin{array}{l}t \text { values } \\
(\mathrm{df}=62)^{a}\end{array}$ & $p$ values ${ }^{a}$ \\
\hline \multicolumn{6}{|c|}{ Hilar region } \\
\hline 1 week & $3.28 \pm 0.27$ & $1.83 \pm 0.10$ & $-44 \%$ & 12.19 & $<0.001$ \\
\hline 2 weeks & $3.52 \pm 0.39$ & $2.15 \pm 0.11$ & $-39 \%$ & 9.15 & $<0.001$ \\
\hline \multicolumn{6}{|c|}{ Granule cell layer } \\
\hline 1 week & $1.84 \pm 0.25$ & $1.70 \pm 0.13$ & $-8 \%$ & 1.00 & NS \\
\hline 2 weeks & $1.95 \pm 0.23$ & $1.95 \pm 0.50$ & $0 \%$ & 0 & NS \\
\hline \multicolumn{6}{|c|}{ Molecular layer } \\
\hline 1 week & $0.59 \pm 0.06$ & $0.59 \pm 0.04$ & $0 \%$ & 0 & NS \\
\hline 2 weeks & $0.56 \pm 0.04$ & $0.61 \pm 0.06$ & $+9 \%$ & -0.89 & NS \\
\hline
\end{tabular}

Control and pilocarpine data are mean ( \pm SEM) number of labeled neurons per $10,000 \mu \mathrm{m}^{2}$, from $n$ dentate gyrus specimens analyzed per group. NS, not significant.

"Student's $t$ test.

the transmitter within the cell bodies could make detection of these neurons difficult with immunohistochemical methods for both GAD and GABA localization. This idea is supported by the findings that many hilar neurons contain high levels of GAD65 mRNA (Houser and Esclapez, 1991; present results) and that colchicine administration, which interferes with axonal transport and thus allows GAD levels to increase in the cell bodies, can lead to an increase in the number of GAD-immunoreactive neurons in the hilus (Ribak et al., 1978; Seress and Ribak, 1983; Kosaka et al., 1988). An alternative explanation for the low numbers of GABA-immunoreactive neurons in the hilus is that both GABA and GAD are synthesized in very low amounts in hilar neurons.

Several findings in the present study suggest that the reduction in the number of GAD mRNA-containing neurons in the hilus of pilocarpine-treated rats reflects an actual loss of these neurons rather than a decrease in GAD mRNA levels within existing neurons. First, large numbers of degenerating neurons were evident in the hilus at $12-72 \mathrm{hr}$ following pilocarpine-induced seizures. Many of these neurons appeared very similar to GAD mRNA-containing neurons in their shape, distribution, and orientation of their proximal dendrites. Permanent damage of hilar neurons is also suggested by a marked decrease in the number of cresyl violet-stained neurons within the hilus at all time points at which GAD mRNA-containing neurons were studied (1-8 weeks following pilocarpine administration). Furthermore, an increase in GFAP immunoreactivity was observed in the hilus at these same times, and such changes are consistent with reactive gliosis associated with neuronal loss. Finally, a decrease in the number of GAD mRNA-containing neurons in the hilus was evident as long as 8 weeks after pilocarpine administration, and such long-lasting changes are likely to reflect a permanent loss of this population of hilar neurons.

The present study is the first to demonstrate a decrease in the number of GAD mRNA-containing neurons in the hilus. However, previous studies have described a loss of several groups of peptide-containing neurons in this region. Somatostatin neurons in the hilus appear to be particularly vulnerable to excitotoxic damage in several models of epilepsy, ischemia, and traumatic head injury (Johansen et al., 1987; Sloviter, 1987; Freund et al., 1991; Ylinen et al., 1991 ; Lowenstein et al., 1992). A loss of somatostatin- and somatostatin mRNA-containing neurons has also been found in the dentate gyrus of humans with temporal lobe epilepsy (deLanerolle et al., 1989; Robbins et al., 1992), where there is often an extensive pattern of cell loss associated with hippocampal sclerosis. In addition, hilar neurons containing neuropeptide $\mathrm{Y}$ (NPY) are susceptible to excitotoxic damage in some models, although their loss is often less pronounced than that of the larger group of somatostatincontaining neurons (Sloviter, 1991b; Sperk et al., 1992). Since NPY is colocalized with somatostatin in some hilar neurons (Köhler et al., 1987), a decrease in the number of neurons labeled for either peptide may reflect a loss of the same neuronal population.

Could these somatostatin- and NPY-containing neurons be subpopulations of GABA neurons within the hilus? The present study reveals a large number of GAD mRNA-containing neurons in the hilus of normal animals, and many of these neurons have virtually the same distribution, sizes, and shapes as the hilar somatostatin- and NPY-containing neurons described by other investigators (Bakst et al., 1986; De Quidt and Emson, 1986; Köhler et al., 1987; Sloviter and Nilaver, 1987; Leranth et al., 1990). In addition, previous studies of the immunohistochemical localization of GAD following colchicine treatment, which increases the cell body labeling of many GAD-containing neurons in the hilus, have demonstrated that GAD is localized in a high percentage of somatostatin-immunoreactive neurons in the hilus (Kosaka et al., 1988). The presently demonstrated vulnerability of the GAD mRNA-containing neurons to excitotoxic damage indicates another similarity to the peptide-containing neurons. Together, these findings provide strong support for the suggestion that the somatostatin- and NPY-containing neurons within the hilus are subclasses of vulnerable GABA neurons within this region. However, the relatively large number of GAD mRNA-containing neurons in the hilus of control animals and the marked loss of these neurons following severe seizure activity raise the possibility that there are other classes of vulnerable GABA neurons in addition to those containing somatostatin and NPY.

A major similarity in the models just discussed is the loss of hilar neurons. However, each of the models differs in the general patterns of brain damage, and further studies will be necessary to determine if the present findings of a loss of GAD mRNAcontaining neurons can be extended to these models. 


\section{Differential vulnerability among $G A D M R N A$-containing neurons}

Despite the vulnerability of many GAD mRNA-containing neurons in the hilus, other groups of GABA neurons in the dentate gyrus appear to be much less susceptible to injury. In the present study, prcsumptivc basket cells, as well as many labeled neurons in the molecular layer, were apparently undamaged. Several previous studies have also noted a preservation of GABAergic basket cells in the dentate gyrus in other experimental models of temporal lobe epilepsy (Davenport et al., 1990a; Feldblum et al., 1990; Sloviter, 1991b) and in human temporal lobe epilepsy (Babb et al., 1989). Likewise, NPY-immunoreactive neurons with similar locations to GABAergic dentate basket cells were apparently undamaged in kainatetreated animals (Sperk et al., 1992).

Reasons for the different sensitivities of some classes of GABA neurons to excitotoxic damage are not known with certainty, but several differences between the groups of GABA neurons could contribute to their differential vulnerability. First, hilar GABA neurons and presumptive basket cells at the granule cell/ hilar border differ in their content of calcium-binding proteins. Many basket cells contain parvalbumin, and a smaller population contains calbindin $\mathrm{D}_{28 \mathrm{~K}}$ (Kosaka et al., 1987; Nitsch et al., 1990; Ribak et al., 1990; Seress et al., 1991). In contrast, many hilar neurons, including mossy cells and somatostatinimmunoreactive and, presumably, GAD mRNA-containing neurons, contain neither calbindin nor parvalbumin (Sloviter, 1989; Freund et al., 1990; Nitsch et al., 1990). The lack of these calcium-binding proteins has been suggested to underlie the susceptibility of many hilar neurons to damage (Sloviter, 1989), and the finding that intracellular injections of a calcium-chelating agent protect some hilar neurons from damage following prolonged stimulation supports this suggestion (Scharfman and Schwartzkroin, 1989). However, a close correspondence between a lack of certain calcium-binding proteins and increased susceptibility to damage is not found for many other groups of neurons in the hippocampal formation, and thus it is likely that additional factors are involved in determining the sensitivity of specific groups of neurons to damage (Freund et al., 1991).

The connectivity of the hilar GABA neurons may also differ from that of the less vulnerable neurons such as the basket cells, and the types and strength of the afferent input could certainly influence the susceptibility of the neurons to excitotoxic damage. However, our present knowledge of the connections of these neurons suggests more similarities than differences. For example, both dentate basket cells and somatostatin-containing hilar neurons receive excitatory input from neurons of the entorhinal cortex (Zipp et al., 1989; Leranth et al., 1990) as well as granule cells of the dentate gyrus (Lubbers and Frotscher, 1987; Leranth et al., 1990), and these two major excitatory pathways are likely to be activated during seizure activity. However, little is known about the relative strength of each of these inputs to the different classes of GABA neurons. Likewise, differences in the responsiveness of GABAergic basket cells and hilar neurons to excitatory, as well as inhibitory, inputs remain to be elucidated.

Finally, GAD mRNA-containing neurons in some regions of the hilus appeared to be somewhat less susceptible to damage than those in other regions. While nearly complete loss of neurons within the central part of the hilus was commonly observed, there was often preservation of some labeled neurons beneath the outer segment of the dorsal blade of the dentate gyrus. Such distribution patterns accounted in part for a quantitatively less severe hilar neuron loss than was often suggested by the qualitative observations. Sperk et al. (1992) also noted that somc somatostatin and NPY neurons in the outer polymorph layer remained intact following kainic acid-induced seizures. Thus, even within the hilus, some groups of GAD mRNA-containing neurons may be more sensitive to damage than others.

\section{Vulnerability of other hilar neurons}

While the loss of GAD mRNA-containing hilar neurons is extensive, the seizure-induced damage may not be restricted to these neurons. The mossy cells are another group of hilar neurons that are particularly sensitive to excitotoxic damage (Sloviter, 1987; Scharfman and Schwartzkroin, 1990b). At the present time, the mossy cells cannot be chemically identified, but they are presumed by some investigators to be excitatory and, possibly, to use glutamate as a neurotransmitter (Amaral, 1978; Ribak et al., 1985; Scharfman and Schwartzkroin, 1988; Frotscher et al., 1991). Because the cell bodies of these neurons cannot be labeled selectively, damage of these neurons has been inferred from the presence of degenerating axon terminals in the inner molecular layer, where the association and commissural fibers of the dentate gyrus, some of which may originate from mossy cells, are known to terminate (Blackstad, 1956; Zimmer, 1971; Swanson et al., 1978; Berger et al., 1981; Laurberg and Sorensen, 1981). Based on such findings, a loss of mossy cells has been suggested following prolonged perforant path stimulation (Sloviter, 1987; Freund et al., 1991). $\Lambda$ band of degenerating terminal-like structures was also observed in the inner molecular layer in the present study, and thus it is likely that hilar mossy cells are among the neurons that are damaged in this pilocarpine model.

\section{Functional consequences of hilar neuron loss}

The relatively large number of GAD mRNA-containing neurons in the hilus of control animals emphasizes the probable importance of these GABA neurons for normal function of the dentate gyrus. Their presence is consistent with physiological evidence that many hilar neurons have inhibitory influences on granule cells, CA3 pyramidal cells, and other hilar neurons (Müller and Misgeld, 1990, 1991; Scharfman et al., 1990).

Figure 7. Relationships among histological findings in the dentate gyrus of a control $(A, C, E, G)$ and an experimental $(B, D, F, H)$ animal. A similar region of the granule cell layer is labeled $G$ in each section to facilitate comparisons among the specimens. Left column:A, In the normal dentate gyrus, numerous cresyl violet-stained neurons are evident in the hilus. $C$, Many GAD mRNA-containing neurons are present in the same region. $E$, No darkly labeled neurons are observed in a control section processed with a silver impregnation method for degenerating neurons. $G$, GFAP-containing astrocytes are present in all regions of the control dentate gyrus but are relatively lightly labeled. Right column:B, At 1 week following pilocarpine-induced seizures, neuronal loss is evident in the dentate hilus in a cresyl violet-stained section. $D$, A marked decrease in the number of GAD mRNA-containing neurons is found in the hilus. $F$, Some darkly labeled, degenerating, hilar neurons are evident in a section processed for neuronal degeneration, and a band (arrowheads) of darkly stained punctate structures, presumed to be degenerating axons and terminals, is present in the inner molecular layer. $H$, Increased GFAP immunoreactivity is evident in all regions of the dentate gyrus, but increased labeling in the hilus and inner molecular layer is particularly striking. Scale bar, $250 \mu \mathrm{m}$. 

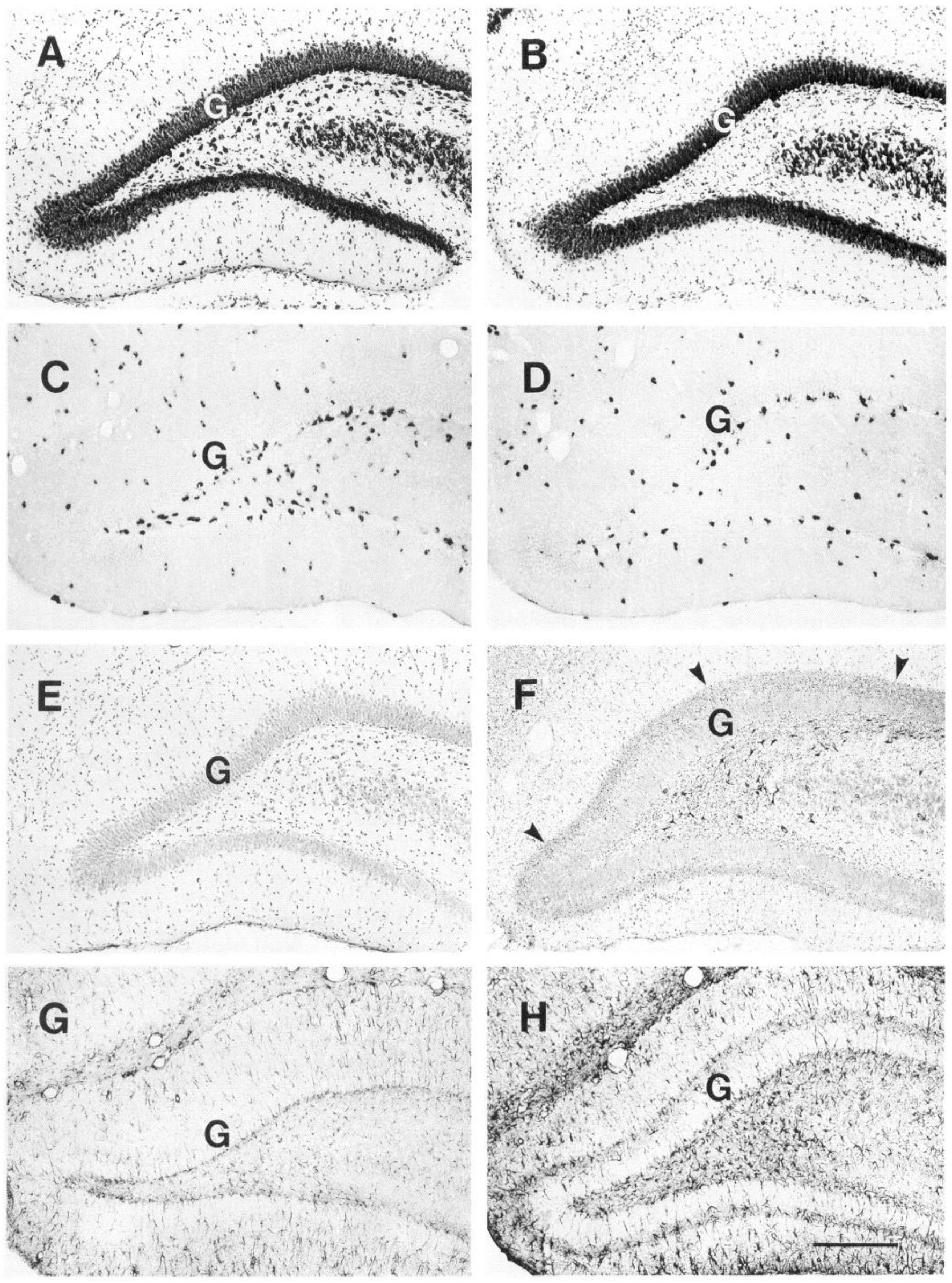

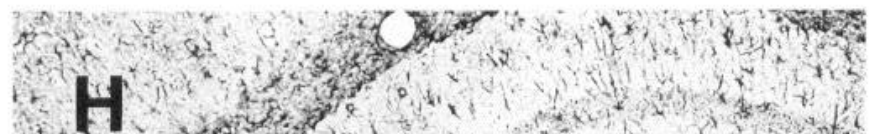
14 ond

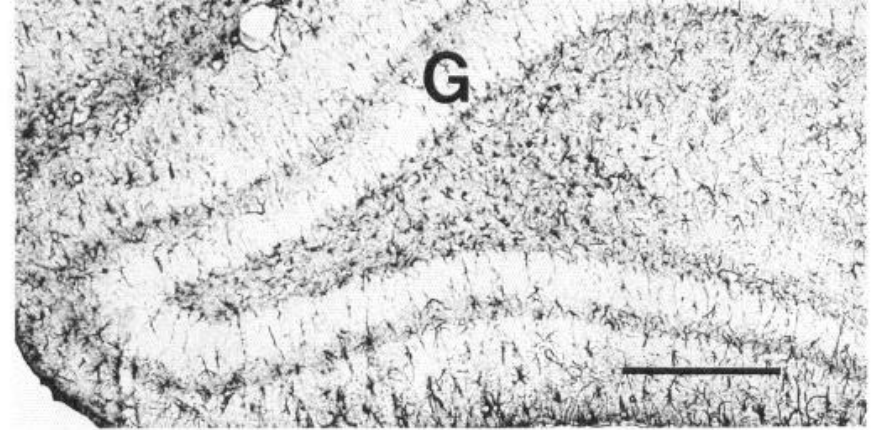


A substantial loss of hilar GABA neurons, such as observed in the present study, might be expected to result in deficits in inhibition. As yet, there have been no electrophysiological descriptions of decreased inhibition in the dentate gyrus of pilocarpine-treated animals. However, persistent deficits in inhibition have been observed following intense perforant path stimulation (Sloviter, 1991a) as well as traumatic head injury (Lowenstein et al., 1992), both of which produce a loss of hilar neurons that appears to be very similar to that observed in the pilocarpine-treated animals. Although several types of alterations could underlie the decreased inhibition, the loss of inhibition directly from damage of hilar GABA neurons appears to be one very plausible explanation.

Mechanisms that do not involve an actual loss of GABA neurons have been suggested to underlie the loss of inhibition of dentate granule cells that has been observed in the perforant path stimulation model (Sloviter, 1991b). One hypothesis is that the loss of hilar mossy cells substantially reduces the excitatory input to the basket cells and, as a result, the basket cells can no longer exert their normal inhibitory control over the granule cells (Sloviter, 1991b). These different explanations for a decrease in inhibition within the dentate gyrus are not mutually exclusive, and multiple mechanisms could underlie the decreased inhibitory control of the granule cells.

The relationship between the loss of GAD mRNA-containing neurons within the hilus and spontaneous recurrent seizures is uncertain. It is tempting to speculate that the loss of hilar GABA neurons contributes to a decreased inhibitory control of the granule cells and CA3 neurons that normally determine the amount of activity allowed to pass to other regions of the hippocampal formation and, subsequently, to widespread regions of the CNS (Collins et al., 1983; Heinemann et al., 1992; Lothman et al., 1992). However, many other factors will influence the balance between inhibition and excitation within the dentate gyrus and CA3 field, and thus the seizure susceptibility of the hippocampal formation in these animals. First, there are other sources of GABAergic inhibition in the hippocampal formation that could compensate for the loss of GABA neurons in the hilus. Several other groups of GABA neurons remain within the dentate gyrus, and these include the basket cells and other GABA neurons, such as axoaxonic neurons, in the granule cell and molecular layers as well as some GABA neurons in the hilus. In addition, extrinsic sources of GABAergic innervation exist, including a projection from the medial septum (Freund and Antal, 1988) and a small GABAergic contribution from the entorhinal cortex (Germroth et al., 1989). Compensation for the loss of the hilar GABA neurons might be accomplished by increased activation of the remaining GABA neurons, increased synthesis of GAD and GABA by these neurons (Feldblum et al., 1990), and, potentially, morphological reorganization of their synaptic connections (Davenport et al., 1990a). If reorganization of remaining GABA neurons were to occur, the functional effects would depend on the types of connections that are formed. It seems unlikely that truly normal patterns of connectivity would be reestablished, and thus, the levels of inhibitory control and the pathways by which this control could be activated might be quite different from normal, and, possibly, less effective.

In addition, alterations in other circuitry have been observed in the chronic pilocarpine-treated animals. Substantial reorganization of granule cell axons (mossy fibers) and their collaterals into the inner molecular layer occurs in these animals (Mello et al., 1990; A. Obenaus and C. R. Houser, unpublished observations) just as it does in several other models of epilepsy (Tauck and Nadler, 1985; Cronin and Dudek, 1988; Sutula et al., 1988; Stanfield, 1989; Qiao et al., 1991) and in humans with temporal lobe epilepsy (deLanerolle et al., 1989, Sutula et al., 1989; Houser et al., 1990; Babb et al., 1991; Masukawa et al., 1992). There is some evidence that the reorganized fibers can increase excitability of the granule cells (Tauck and Nadler, 1985), particularly when inhibition is depressed (Pokorny et al., 1991; Cronin et al., 1992). There arc also suggestions that the reorganized mossy fibers may have restorative effects by increasing the excitatory input to remaining basket cells, which in turn could increase their inhibitory control over the granule cells (Sloviter, 1992). However, if mossy fiber reorganization were to favor increased excitability of the granule cells, the combination of a loss of some inhibition of the granule cells, as suggested by the morphological findings in the present study, and an abnormal recurrent excitatory input to the granule cells, through mossy fiber reorganization, could lead to a greater increase in the excitability of the dentate granule cells than either alteration alone.

\section{Concluding remarks}

The present findings demonstrate conclusively that some groups of GAD mRNA-containing neurons are extremely sensitive to seizure-induced damage. At the same time, the results emphasize that not all populations of presumptive GABA neurons, even within the same brain region, are equally vulnerable to the excitotoxic damage induced in this model. These findings may have broader implications for studies of alterations of GABA neurons in other brain regions and in other neurological disorders, and argue against considering GABA neurons as a homogeneous group of neurons that are similarly vulnerable to damage. The specific synaptic connections, types of receptors, firing patterns, and content of calcium-binding proteins and peptides may be critical for determining the susceptibility of subclasses of GABA neurons to damage.

\section{References}

Amaral DG (1978) A Golgi study of cell types in the hilar region of the hippocampus in the rat. J Comp Neurol 182:851-914.

Amaral DG, Campbell MJ (1986) Transmitter systems in the primate dentate gyrus. Hum Neurobiol 5:169-180.

Babb TL, Pretorius JK, Kupfer WR, Crandall PH (1989) Glutamate decarboxylase-immunoreactive neurons are preserved in human epileptic hippocampus. J Neurosci 9:2562-2574.

Babb TL, Kupfer WR, Pretorius JK, Crandall PH, Levesque MF (1991) Synaptic reorganization by mossy fibers in human epileptic fascia dentata. Neuroscience 42:351-363.

Baez LA, Eskridge NK, Schein R (1976) Postnatal development of dopaminergic and cholinergic catalepsy in the rat. Eur $\mathbf{J}$ Pharmacol 36:155-162.

Bakst I, Avendano C, Morrison JH, Amaral DG (1986) An experimental analysis of the origins of somatostatin-like immunoreactivity in the dentate gyrus of the rat. J Neurosci 6:1452-1462.

Benson DL, Isackson PJ, Hendry SHC, Jones EG (1991) Differential gene expression for glutamic acid decarboxylase and type II calciumcalmodulin-dependent protein kinase in basal ganglia, thalamus, and hypothalamus of the monkey. J Neurosci 11:1540-1564.

Berger TW, Semple-Rowland S, Bassett JL (1981) Hippocampal polymorph neurons are the cells of origin for ipsilateral association and commissural afferents to the dentate gyrus. Brain Res 215:329-336.

Blackstad TW (1956) Commissural connections of the hippocampal region in the rat with special reference to their mode of termination. J Comp Neurol 105:417-537. 
Cavalheiro EA (1990) GAD-immunoreactive neurons arc prescrved in the hippocampus of rats with spontaneous recurrent seizures. Braz J Med Biol Res 23:555-558.

Cavalheiro EA, Silva DF, Turski WA, Calderazzo-Filho LS, Bortolotto ZA, Turski L (1987) The susceptibility of rats to pilocarpine-induced seizures is age-dependent. Dev Brain Res 37:43-58.

Cavalheiro EA, Leite JP, Bortolotto ZA, Turski WA, Ikonomidou C, Turski L (1991) Long-term effects of pilocarpine in rats: structural damage of the brain triggers kindling and spontaneous recurrent seizures. Epilepsia 32:778-782

Chesselet M-F, Weiss L, Wuenschell C, Tobin AJ, Affolter H-U (1987) Comparative distribution of mRNAs for glutamic acid decarboxylase, tyrosine hydroxylase, and tachykinins in the basal ganglia: an in situ hybridization study in the rodent brain. J Comp Neurol 262:125140.

Collins RC, Tearse RG, Lothman EW (1983) Functional anatomy of limbic seizures: focal discharges from medial entorhinal cortex in rat. Brain Res 280:25-40.

Cronin J, Dudek FE (1988) Chronic seizures and collateral sprouting of dentate mossy fibers after kainic acid treatment in rats. Brain Res 474:181-184.

Cronin J, Obenaus A, Houser CR, Dudek FE (1992) Electrophysiology of dentate granule cells after kainate-induced synaptic reorganization of the mossy fibers. Brain Res 573:305-310.

Davenport CJ, Brown WJ, Babb TL (1990a) Sprouting of GABAergic and mossy fiber axons in dentate gyrus following intrahippocampal kainate in the rat. Exp Neurol 109:180-190.

Davenport CJ, Brown WJ, Babb TL (1990b) GABAergic neurons are spared after intrahippocampal kainate in the rat. Epilepsy Res 5:2842.

deLanerolle NC, Kim JH, Robbins RJ, Spencer DD (1989) Hippocampal interneuron loss and plasticity in human temporal lobe epilepsy. Brain Res 495:387-395.

De Quidt ME, Emson PC (1986) Distribution of neuropeptide Y-like immunoreactivity in the rat central nervous system-II. Immunohistochemical analysis. Neuroscience 18:545-618.

Erlander MG, Tobin AJ (1991) The structural and functional heterogeneity of glutamic acid decarboxylase: a review. Neurochem Res 16: 215-226.

Erlander MG, Tillakaratne NJK, Feldblum S, Patel N, Tobin AJ (1991) Two genes encode distinct glutamate decarboxylases. Neuron 7:91100.

Esclapez M, Tillakaratne NJK, Tobin AJ, Houser CR (1993) Conparative localization of mRNAs encoding two forms of glutamic acid decarboxylase with nonradioactive in situ hybridization methods. J Comp Neurol 331:339-362.

Feldblum S, Ackermann RF, Tobin AJ (1990) Long-term increase of glutamate decarboxylase mRNA in a rat model of temporal lobe epilepsy. Neuron 5:361-371.

Ferraguti F, Zoli M, Aronsson M, Agnati LF, Goldstein M, Filer D, Fuxe K (1990) Distribution of glutamic acid decarboxylase messenger RNA-containing nerve cell populations of the male rat brain. J Chem Neuroanat 3:377-369.

Franck JE, Kunkel DD, Baskin DG, Schwartzkroin PA (1988) Inhibition in kainate-lesioned hyperexcitable hippocampi: physiologic autoradiographic, and immunocytochemical observations. J Neurosci 8:1991-2002.

Freund TF, Antal M (1988) GABA-containing neurons in the septum control inhibitory interneurons in the hippocampus. Nature 336:170173.

Freund TF, Buzsáki G, Leon A, Baimbridge KG, Somogyi P (1990) Relationship of neuronal vulnerability and calcium binding protein immunoreactivity in ischemia. Exp Brain Res 83:55-66.

Freund TF, Ylinen A, Miettinen R, Pitkänen A, Lahtinen H, Baimbridge KG, Riekkinen PJ (1991) Pattern of neuronal death in the rat hippocampus after status epilepticus. Relationship to calcium binding protein content and ischemic vulnerability. Brain Res Bull 28:27-38.

Frotscher M, Seress L, Schwerdtfeger WK, Buhl E (1991) The mossy cells of the fascia dentata: a comparative study of their fine structure and synaptic connections in rodents and primates. J Comp Neurol 312:145-163.

Gallyas F, Wolff JR, Bottcher H, Zaborszky L (1980) A reliable and sensitive method to localize terminal degeneration and lysosomes in the central nervous system. Stain Technol 55:299-306.

Gamrani H, Onteniente B, Seguela P, Geffard M, Calas A (1986) Gam- ma-aminobutyric acid-immunoreactivity in the rat hippocampus. A light and electron microscopic study with anti-GABA antibodies. Brain Res 364:30-38.

Germroth P, Schwerdtfeger WK, Buhl EH (1989) GABAergic neurons in the entorhinal cortex project to the hippocampus. Brain Res 494: 187-192.

Heinemann U, Beck H, Dreier JP, Stabel J, Zhang CL (1992) The dentate gyrus as a regulated gate for the propagation of epileptiform activity. In: Epilepsy research, Suppl 7, The dentate gyrus and its role in seizures (Ribak CE, Gall CM, Mody I, eds), pp 273-280. Amsterdam: Elsevier.

Houser CR (1991) GABA neurons in seizure disorders: a review of immunocytochemical studies. J Neurochem 16:295-308.

Houser CR, Esclapez M (1991) Localization of mRNAs encoding two forms of glutamatc decarboxylase in the hippocampal formation. Soc Neurosci Abstr 17:416.

Houser CR, Miyashiro JE, Swartz BE, Walsh GO, Rich JR, DelgadoEscueta AV (1990) Altered patterns of dynorphin immunoreactivity suggest mossy fiber reorganization in human hippocampal epilepsy. J Neurosci 10:267-282.

Johansen FF, Zimmer J, Diemer NH (1987) Early loss of somatostatin neurons in dentate hilus after cerebral ischemia in the rat precedes CA-1 pyramidal cell loss. Acta Neuropathol (Berl) 73:1 10-114.

Julien J-F, Legay F, Dumas S, Tappaz M, Mallet J (1987) Molecular cloning, expression and in situ hybridization of rat brain glutamic acid decarboxylase messenger RNA. Neurosci Lett 73:173-180.

Kaufman DL, Houser CR, Tobin AJ (1991) Two forms of the gammaaminobutyric acid synthetic enzyme glutamate decarboxylase have distinct intraneuronal distributions and cofactor interactions. J Neurochem 56:720-723.

Köhler C (1983) Neuronal degeneration after intracerebral injections of excitotoxins. A histological analysis of kainic acid, ibotenic acid and quinolinic acid lesions in the rat brain. In: Wenner-Gren Center international symposium series, Vol 39, Excitotoxins (Fuxe K, Roberts P, Schwarcz R, eds), pp 99-111. London: Macmillan.

Köhler C, Eriksson LG, Davies S, Chan-Palay V (1987) Co-localization of neuropeptide tyrosine and somatostatin immunoreactivity in neurons of individual subfields of the rat hippocampal region. Neurosci Lett 78:1-6.

Kosaka T, Katsumaru H, Hama K, Wu J-Y, Heizmann CW (1987) GABAergic neurons containing the $\mathrm{Ca}^{2+}$-binding protein parvalbumin in the rat hippocampus and dentate gyrus. Brain Res 419:119 130.

Kosaka T, Wu J-Y, Benoit R (1988) GABAergic neurons containing somatostatin-like immunoreactivity in the rat hippocampus and dentate gyrus. Exp Brain Res 71:388-398.

Krnjević K (1983) GABA-mediated inhibitory mechanisms in relation to epileptic discharges. Neurol Neurobiol 2:249-280.

Laurberg S, Sorensen KE (1981) Associational and commissural collaterals of neurons in the hippocampal formation (hilus fasciae dentatae and subfield CA3). Brain Res 212:287-300.

Leite JP, Bortolotto ZA, Cavalheiro EA (1990) Spontaneous recurrent seizures in rats: an experimental model of partial epilepsy. Neurosci Biobchav Rcv 14:511-517.

Leranth C, Malcolm AJ, Frotscher M (1990) Afferent and efferent synaptic connections of somatostatin-immunoreactive neurons in the rat fascia dentata. J Comp Neurol 295:111-122.

Lorente de Nó R (1934) Studies on the structure of the central cortex. II. Continuation of the study of the ammonic system. J Psychol Neurol 46:113-177.

Lothman EW, Stringer JL, Bertram EH (1992) The dentate gyrus as a control point for seizures in the hippocampus and beyond. In: Epilepsy research, Suppl 7, The dentate gyrus and its role in seizures (Ribak CE, Gall CM, Mody I, eds), pp 301-313. Amsterdam: Elsevier.

Lowenstein DH, Thomas MJ, Smith DH, McIntosh TK (1992) Selective vulnerability of dentate hilar neurons following traumatic brain injury: a potential mechanistic link between head trauma and disorders of the hippocampus. J Neurosci 12:4846-4853.

Lu W, Haber SN (1992) In situ hybridization histochemistry: a new method for processing material stored for several years. Brain Res 578:155-160.

Lubbers K, Frotscher M (1987) Fine structure and synaptic connections of identified neurons in the rat fascia dentata. Anat tembryol (Berl) 177:1-14. 
Martin DL, Rimvall K (1993) Regulation of $\gamma$-aminobutyric acid synthesis in the brain. J Neurochem 60:395-407.

Martin DL, Martin SB, Wu SJ, Espina N (1991a) Regulatory properties of brain glutamate decarboxylase (GAD): the apoenzyme of GAD is present principally as the smaller of two molecular forms of GAD in brain. J Neurosci 11:2725-2731.

Martin DL, Martin SB, Wu SJ, Espina N (1991b) Cofactor interactions and the regulation of glutamate decarboxylase activity. Neurochem Res 16:243-249.

Masukawa LM, Uruno K, Sperling M, O'Connor MJ, Burdette LJ (1992) The functional relationship between antidromically evoked field responses of the dentate gyrus and mossy fiber reorganization in temporal lobe epileptic patients. Brain Res 579:119-127.

Mello LEAM, Cavalheiro EA, Babb TL, Kupfer WR, Pretorius JK, Tan AM, Finch DM (1990) Pilocarpine-induced status epilepticus leads to chronic seizures and mossy fiber sprouting in the hippocampus. Epilepsia 31:675.

Mercugliano M, Soghomonian J-J, Qin Y, Nguyen HQ, Feldblum S, Erlander MG, Tobin AJ, Chesselet M-F (1992) Comparative distribution of messenger RNAs encoding glutamic acid decarboxylases $\left(M_{r} 65,000\right.$ and $\left.M_{r} 67,000\right)$ in the basal ganglia of the rat. J Comp Neurol 318:245-254.

Mugnaini E, Oertel WH (1985) An atlas of the distribution of GABAergic neurons and terminals in the rat CNS as revealed by GAD immunohistochemistry. In: Handbook of chemical neuroanatomy, Vol 4, GABA and neuropeptides in the CNS, Pt I (Bjorklund A, Hokfelt T, eds), pp 436-608. Amsterdam: Elsevier.

Müller W, Misgeld U (1990) Inhibitory role of dentate hilus neurons in guinea pig hippocampal slicc. J Ncurophysiol 64:46-56.

Müller W, Misgeld U (1991) Picrotoxin- and 4-aminopyridine-induced activity in hilar neurons in the guinea pig hippocampal slice. J Neurophysiol 65:141-147.

Nadler JV, Evenson DA (1983) Use of excitatory amino acids to make axon-sparing lesions of hypothalamus. Methods Enzymol 103:393400.

Nitsch R, Soriano E, Frotscher M (1990) The parvalbumin-containing nonpyramidal neurons in the rat hippocampus. Anat Embryol (Berl) $181: 413-425$.

Obenaus A, Esclapez M, Houser CR (1992) Loss of GAD mRNAcontaining neurons in the hilus of the dentate gyrus following pilocarpine-induced seizures. Soc Neurosci Abstr 18:555.

Pokorny J, Schwartzkroin PA, Franck JE (1991) Physiologic and morphologic characteristics of granule cells from human epileptic hippocampus. Epilepsia 32:46.

Qiao X, Chafetz RS, Noebels JL (1991) Hippocampal mossy fiber outgrowth in a mutant with inherited spike wave seizures. Soc Neurosci Abstr 17:169.

Ribak CE, Seress L (1983) Five types of basket cell in the hippocampal dentate gyrus: a combined Golgi and electron microscopic study. J Neurocytol 12:577-597.

Ribak CE, Vaughn JE, Saito K (1978) Immunocytochemical localization of glutamic acid decarboxylase in neuronal somata following colchicine inhibition of axonal transport. Brain Res 140:315-332.

Ribak CE, Harris AB, Vaughn JE, Roberts E (1979) Inhibitory, GABAergic nerve terminals decrease at sites of focal epilepsy. Science 205:211-214.

Ribak CE, Seress L, Amaral DG (1985) The development, ultrastructure and synaptic connections of the mossy cells of the dentate gyrus. J Neurocytol 14:835-857.

Ribak CE, Nitsch R, Seress L (1990) Proportion of parvalbuminpositive basket cells in the GABAergic innervation of pyramidal and granule cells of the rat hippocampal formation. J Comp Neurol 300: 449-461.

Robbins RJ, Brines ML, Kim JH, Adrian T, deLanerolle NC, Welsh $S$, Spencer DD (1992) A selective loss of somatostatin in the hippocampus of patients with temporal lobe epilepsy. Ann Neurol 29: 325-332.

Roberts E (1984) Gamma-aminobutyric acid (GABA): from discovery to visualization of GABAergic neurons in the vertebrate nervous system. In: Actions and interactions of GABA and benzodiazepines (Bowery NG, ed), pp 1-25. New York: Raven.

Scharfman HE, Schwartzkroin PA (1988) Electrophysiology of morphologically identified mossy cells of the dentate hilus recorded in guinea pig hippocampal slices. J Neurosci 8:3812-3821.

Scharfman HE, Schwartzkroin PA (1989) Protection of dentate hilar cells from prolonged stimulation by intracellular calcium chelation. Science 246:257-260.

Scharfman HE, Schwartzkroin PA (1990a) Responses of cells of the rat fascia dentata to prolonged stimulation of the perforant path: Sensitivity of hilar cells and changes in granule cell excitability. Neuroscience 35:491-504.

Scharfman HE, Schwartzkroin PA (1990b) Consequences of prolonged afferent stimulation of the rat fascia dentata: epileptiform activity in area CA3 of hippocampus. Neuroscience 35:505-517.

Scharfman HE, Kunkel DD, Schwartzkroin PA (1990) Synaptic connections of dentate granule cells and hilar neurons: results of paired intracellular recordings and intracellular horseradish peroxidase injections. Neuroscience 37:693-707.

Seress L, Ribak CE (1983) GABAergic cells in the dentate gyrus appear to be local circuit and projection neurons. Exp Brain Res 50:173182 .

Seress L, Gulyas AI, Freund TF (1991) Parvalbumin- and calbindin $\mathrm{D}_{28 \mathrm{k}}$-immunoreactive neurons in the hippocampal formation of the macaque monkey. J Comp Neurol 313:162-177.

Sloviter RS (1983) "Epileptic" brain damage in rats induced by sustained electrical stimulation of the perforant path. I. Acute electrophysiological and light microscopic studies. Brain Res Bull 10:675697.

Sloviter RS (1987) Decreased hippocampal inhibition and a selective loss of interneurons in experimental epilepsy. Science 235:73-76.

Sloviter R.S (1989) Calcium-binding protein (calbindin-D28k) and parvalbumin immunocytochemistry: localization in the rat hippocampus with specific reference to the selective vulnerability of hippocampal ncurons to scizurc activity. J Comp Ncurol 280:183-196.

Sloviter RS (1991a) Feedforward and feedback inhibition of hippocampal principal cell activity evoked by perforant path stimulation: GABA-mediated mechanisms that regulate excitability in vivo. Hippocampus $1: 31-40$

Sloviter RS (1991b) Permanently altered hippocampal structure, excitability, and inhibition after experimental status epilepticus in the rat: the "dormant basket cell" hypothesis and its possible relevance to temporal lobe epilepsy. Hippocampus 1:41-66.

Sloviter RS (1992) Possible functional consequences of synaptic reorganization in the dentate gyrus of kainate-treated rats. Neurosci Lett 137:91-96.

Sloviter RS, Damiano BP (1981) On the relationship between kainic acid-induced epileptiform activity and hippocampal neuronal damage. Neuropharmacology 20:1003-1011.

Sloviter RS, Nilaver G (1987) Immunocytochemical localization of GABA-, cholecystokinin-, vasoactive intestinal polypeptide-, and somatostatin-like immunoreactivity in the area dentata and hippocampus of the rat. J Comp Neurol 256:42-60.

Sperk G, Marksteiner J, Gruber B, Bellmann R, Mahata M, Ortler M (1992) Functional changes in neuropeptide $Y$ - and somatostatincontaining neurons induced by limbic seizures in the rat. Neuroscience 50:831-846.

Stanfield BB (1989) Excessive intra- and supragranular mossy fibers in the dentate gyrus of tottering $(\mathrm{tg} / \mathrm{tg})$ mice. Brain Res 480:294-299.

Sutula T, Xiao-Xian H, Cavazos J, Scott G (1988) Synaptic reorganization in the hippocampus induced by abnormal functional activity. Science 239:1147-1150.

Sutula T, Cascino G, Cavazos J, Parada I, Ramirez L (1989) Mossy fiber synaptic reorganization in the epileptic human temporal lobe. Ann Neurol 26:321-330.

Swanson LW, Wyss JM, Cowan WM (1978) An autoradiographic study of the organization of intrahippocampal association pathways in the rat. J Comp Neurol 181:681-716.

Tauck DL, Nadler JV (1985) Evidence of functional mossy fiber sprouting in hippocampal formation of kainic acid-treated rats. $J$ Neurosci 5:1016-1022

Turski L, Cavalheiro EA, Sieklucka-Dziuba M, Ikonomidou-Turski C, Czuczwar SJ, Turski WA (1986) Seizures produced by pilocarpine: neuropathological sequelae and activity of glutamate decarboxylase in the rat forebrain. Brain Res 398:37-48.

Turski L, Ikonomidou C, Turski WA, Bortolotto ZA, Cavalheiro EA (1989) Review: cholinergic mechanisms and epileptogenesis. The seizures induced by pilocarpine: a novel experimental model of intractable epilepsy. Synapse 3:154-171.

Turski WA, Cavalheiro EA, Schwarz M, Czuczwar SJ, Kleinrok Z, Turski L (1983) Limbic seizures produced by pilocarpine in rats: a 
behavioural, electroencephalographic and neuropathological study. Behav Brain Res 9:315-336.

Watson RE Jr, Wiegand SJ, Clough RW, Hoffman GE (1986) Use of cryoprotectant to maintain long-term peptide immunoreactivity and tissue morphology. Peptides 7:155-159.

Wuenschell CW, Fisher RS, Kaufman DL, Tobin AJ (1986) In situ hybridization to localize mRNA encoding the neurotransmitter synthetic enzyme glutamate decarboxylase in mouse cerebellum. Proc Natl Acad Sci USA 83:6193-6197.

Ylinen A, Valjakka A, Lahtinen H, Miettinen R, Freund TF, Riekkinen
P (1991) Vigabatrin pre-treatment prevents hilar somatostatin cell loss and the development of interictal spiking activity following sustained stimulation of the perforant path. Neuropeptides 19:205-211.

Zimmer J (1971) Ipsilateral afferents to the commissural zone of the fascia dentata, demonstrated in decommissurated rats by silver impregnation. J Comp Neurol 142:393-416.

Zipp F, Nitsch R, Soriano E, Frotscher M (1989) Entorhinal fibers form synaptic contacts on parvalbumin-immunoreactive neurons in the rat fascia dentata. Brain Res 495:161-166. 